\title{
An Assessment of Depression, Anxiety, and Stress among Nationally Certified EMS Professionals
}

\section{THESIS}

Presented in Partial Fulfillment of the Requirements for the Degree Master of Science in the Graduate School of The Ohio State University

By

Melissa A. Bentley BS, NREMT-P

Graduate Program in Public Health

The Ohio State University

2011

Master's Examination Committee:

Dr. J. Mac Crawford, Advisor

Dr. J.R. Wilkins III 


\section{Copyright by}

Melissa A. Bentley

2011 


\begin{abstract}
Among EMS professionals, occupational exposures in mental illness literature are not well-represented. Currently, no literature exists examining the prevalence of mental illness in a large national cohort of EMS professionals. As such, the purpose of this study is to address the lack of scientific knowledge and evidence in the field of mental illness among EMS professionals.

The objectives of this master's thesis are three fold. The first objective is to estimate the prevalence and severity of depression, anxiety, and stress among a cohort of nationally certified EMS professionals. Because other healthcare professions may have similar occupational exposures related to mental illness, the second objective of this study is a comparison of nationally certified EMS professionals' depression, anxiety, and stress prevalence to other healthcare professions. The third objective of this master's thesis is the determination of differences between cases and controls (defined by the 21question Depression, Anxiety, and Stress Scale (DASS-21)) from the same cohort with respect to clinical depression, anxiety, stress, and demographic and work-life characteristics.
\end{abstract}

In accordance with previous methodologies, a questionnaire was included as part of the 2009 biennial recertification paperwork mailed to all nationally certified EMS 
professionals prior to their 2009 expiration date. This questionnaire contained demographic and work-life characteristic items as well as the DASS-21. Three outcome variables of interest were derived from the DASS-21: clinical depression, clinical anxiety, and clinical stress. Any scores above "normal" for each of the outcomes were determined to be a case and controls were defined as those whose scores fell below the case cutpoint. A complete case-control analysis was performed for each of the three outcome variables. Independent variables were chosen based on previous methodologies and plausibility. A total of 15 independent variables were assessed.

The prevalence of depression among the cohort was found to be $6.8 \%$, the prevalence of anxiety was found to be $6.0 \%$, and the prevalence of stress was $5.9 \%$.

In the final logistic regression models, certification level, service type, general health, exercise, smoking status, and age were found to be statistically significant in each of the depression, anxiety, and stress models. Further, years of experience, race, and education level was found to be unique only to the depression and stress models. Marital status was found to be statistically significant in only the depression and anxiety models. Lastly, gender was unique to the depression logistic model.

This study was able to identify statistically significant demographic and work-life characteristic variables that predicted depression, anxiety, and stress. Future research should attempt to follow EMS professionals prospectively to determine specific characteristics associated with occupational traumatic exposure and the development of clinical depression, anxiety, and stress. Likewise, specific research efforts should be 
undertaken to establish early recognition criteria in EMS professionals to ensure adequate and quick treatment of mental disorders. 


\title{
Dedication
}

\author{
Dedicated to all those who put
} their lives on the line to serve others.

It is an honor and privilege to serve with you. 


\section{Acknowledgments}

First and foremost, thank you to Dr. J Mac Crawford. Without your continual support, teaching and guidance, this project would not have been completed. Thank you to Dr. Jay Wilkins for your guidance throughout this master's thesis.

Thank you to the National Registry of Emergency Medical Technician’s for the continued commitment of the pursuit of evidence-based prehospital medicine. Lastly, thank you to Tony Fernandez and Jon Studnek, my colleagues, my mentors and my friends. Your endless support and confidence has inspired me to continuously strive to improve our profession through research. 
Vita

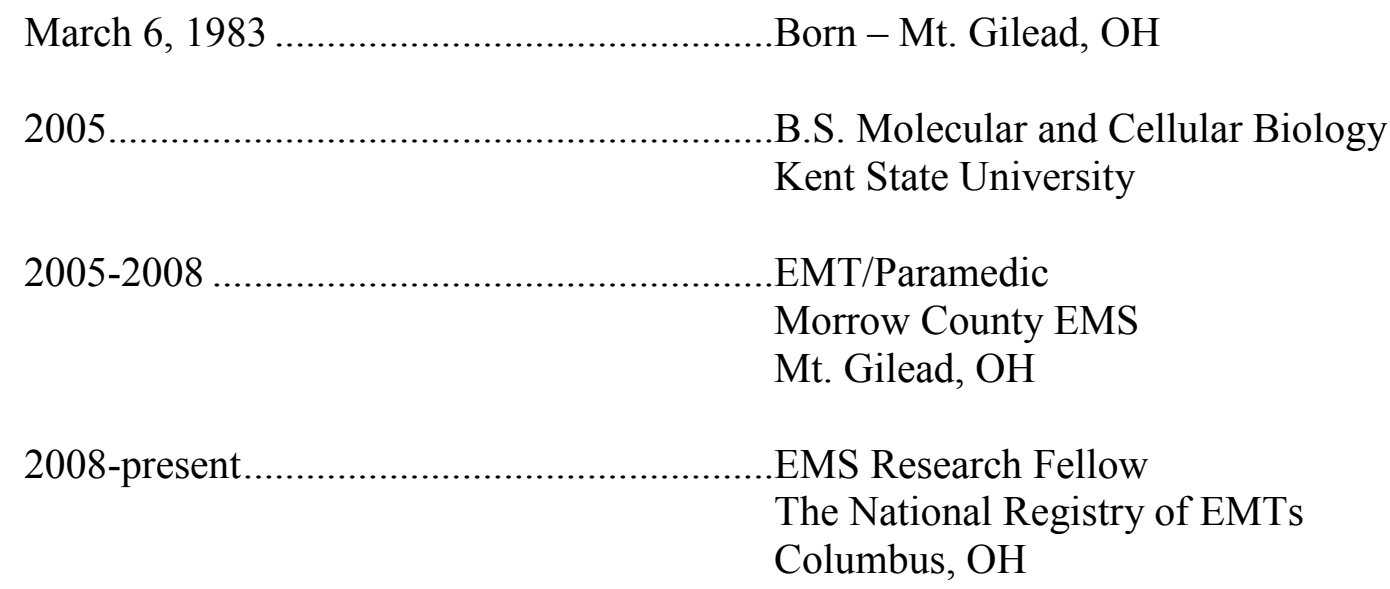

Publications

Fernandez AR, Margolis GS, Studnek JR, Crawford JM, Bentley MA, Marcozzi D (2011). Disaster Preparedness of Nationally Certified EMS Professionals. Academic Emergency Medicine; 18:403-412

Studnek JR, Bentley MA, Crawford JM, Fernandez AR (2010). An Assessment of Key Health Indicators among Emergency Medical Services Professionals. Prehospital Emergency Care; $14: 14-20$

Barnett DJ, Levine R, Thompson CB, Wijetunge GU, Oliver AL, Bentley MA, Neubert PD, Pirrallo RG, Links JM, Balicer RD (2010). Gauging U.S. Emergency Medical Services Workers' Willingness to Respond to Pandemic Influenza Using a Threat-and Efficacy-Based Assessment Framework. PLoS ONE;5:e9856

Fields of Study

Major Field: Public Health 
Table of Contents

Page

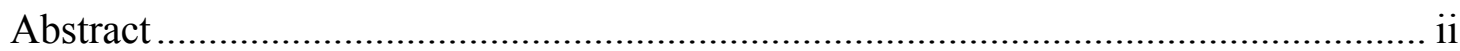

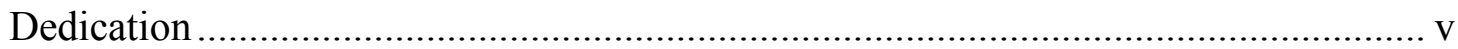

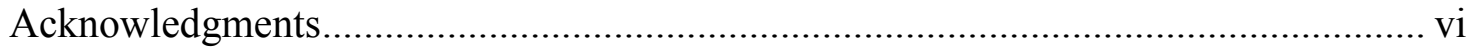

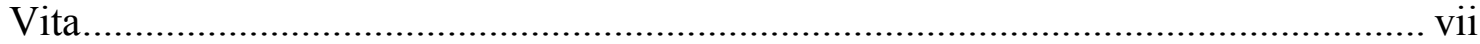

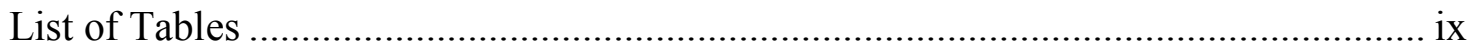

Chapters:

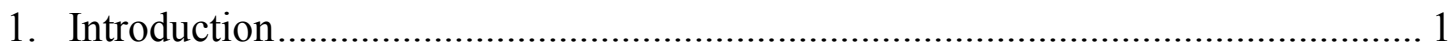

1.1 Emergency Medical Services............................................................... 1

1.2 Occupational Health and Exposure in EMS ......................................... 2

1.3 Mental Health Disease Burden ................................................................... 4

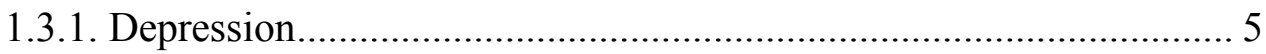

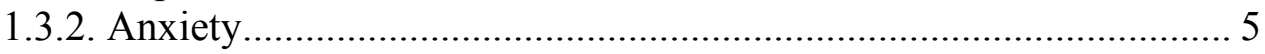

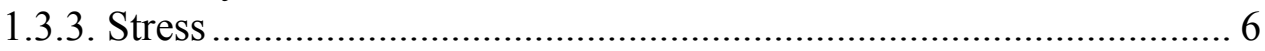

1.4 Occupational Exposure Related to Mental Health.................................. 7

1.5 Effects of Occupational Exposure to Traumatic Events ........................... 8

1.6 Study Objectives and Hypotheses .................................................. 10

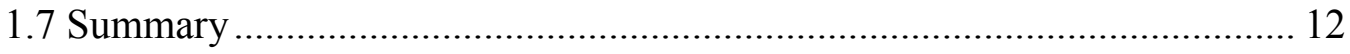

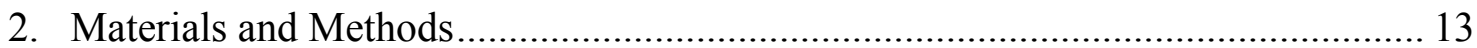

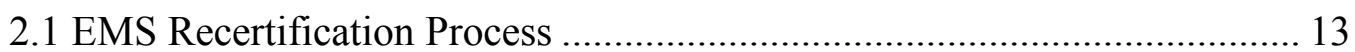

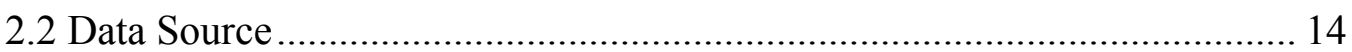

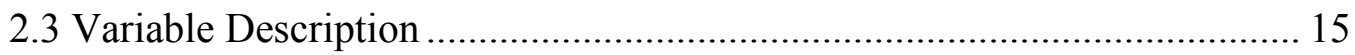

2.3.1. Demographic Variables ........................................................... 15

2.3.2. Occupational Characteristic Variables............................................. 16

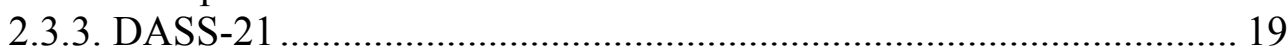

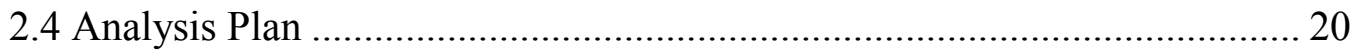




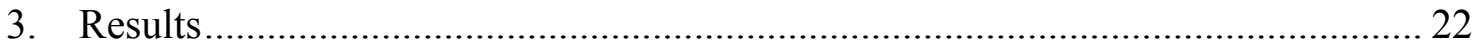

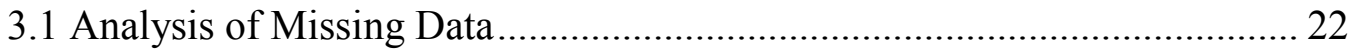

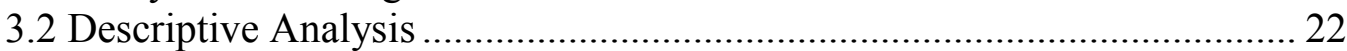

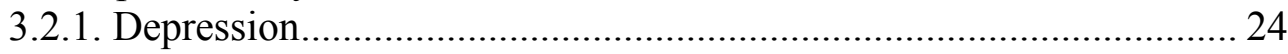

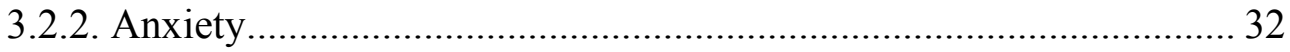

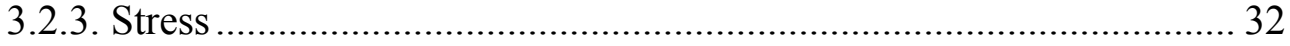

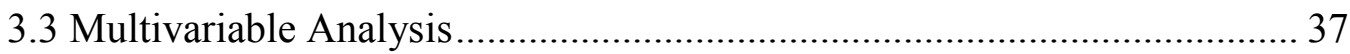

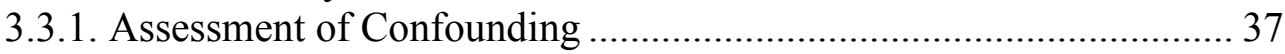

3.3.2. Assessment of Possible Interactions ............................................ 37

3.3.3. Final Logistic Regression Model .................................................. 38

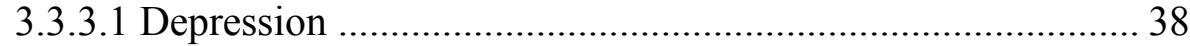

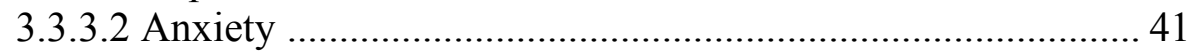

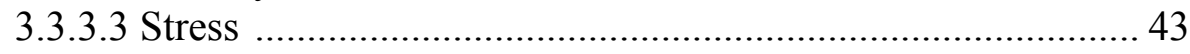

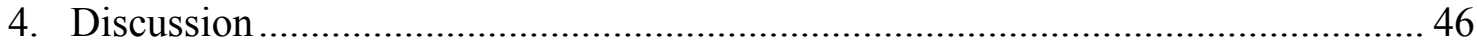

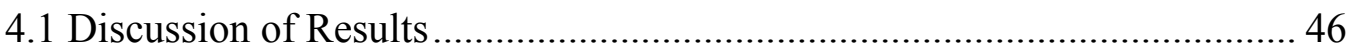

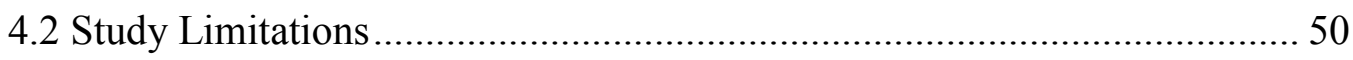

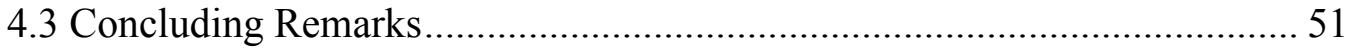

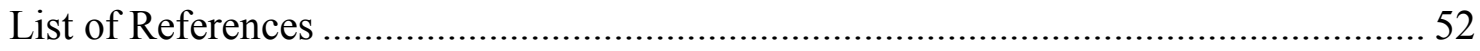

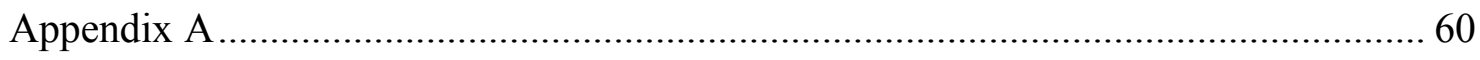

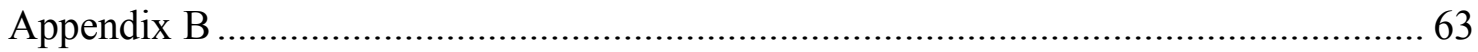

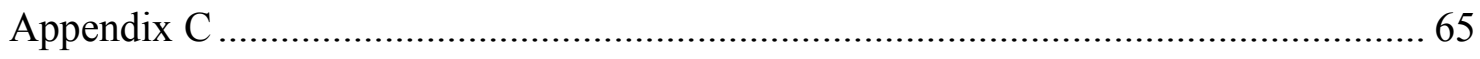

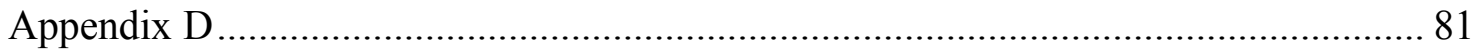




\section{List of Tables}

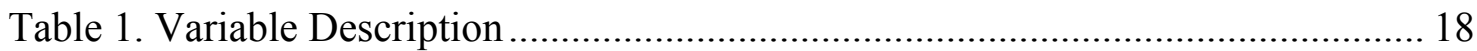

Table 2. Severity of Depression, Anxiety, and Stress............................................. 23

Table 3. Depression Summary Statistics for Categorical Variables ........................... 24

Table 4. Depression Summary Statistics for Continuous Variables ............................ 26

Table 5. Anxiety Summary Statistics for Categorical Variables ................................ 28

Table 6. Anxiety Summary Statistics for Continuous Variables ................................ 30

Table 7. Stress Summary Statistics for Categorical Variables ................................ 32

Table 8. Stress Summary Statistics for Continuous Variables .................................. 35

Table 9. Depression: Final Logistic Regression Model......................................... 38

Table 10. Anxiety: Final Logistic Regression Model ........................................... 41

Table 11. Stress: Final Logistic Regression Model .................................................. 43 


\section{Chapter 1: Introduction}

\subsection{Emergency Medical Services}

Emergency Medical Service (EMS) professionals deliver around the clock vital and lifesaving prehospital emergency care to individuals involved in both medical and traumatic emergencies. ${ }^{1}$ As such, the EMS profession is an integral component of the U.S. healthcare system. There are currently two nationally recognized levels of EMS professionals, the EMT-Basic, and the Paramedic. ${ }^{2}$ EMT-Basics are trained to deliver prehospital care that includes, but is not limited to, Cardiopulmonary Resuscitation (CPR), basic airway management, cervical spine immobilization, and bandaging. ${ }^{2}$ Likewise, Paramedics utilize training to deliver emergent care such as advanced airway management, intravenous access initiation, medication administration, and advanced cardiac life support. ${ }^{2}$

EMS professionals must maintain state licensure to practice. Each state differs on the requirements to gain and to maintain an EMS license, currently 46 states in the U.S. require initial national certification to obtain a state license. ${ }^{3}$ In this country, the national certification body is the National Registry of Emergency Medical Technicians (NREMT). The NREMT is the only EMS certification body that provides a legally defensible and psychometrically sound cognitive and psychomotor examination to test entry level 
competence. ${ }^{4}$ To gain national certification, EMS candidates must attend a state approved EMS education program, and successfully complete both a cognitive and psychomotor examination. ${ }^{5,6}$ To maintain national certification, EMS professionals must complete 72 hours of continuing education hours every two years. ${ }^{7,8}$

In 2004, it was estimated that over 900,000 EMS professionals were currently practicing in the U.S., but the actual number is unknown. ${ }^{9}$ This uncertainty lies within in the design of the EMS system itself. Forty-six states require national certification to gain state licensure, only eight states require national certification to be maintained. ${ }^{3}$ Currently, there is no database that includes both nationally certified and state licensed EMS professionals. However, the NREMT database is the largest database in the United States of current nationally certified EMS professionals. In June of 2010, it was estimated that there were over 192,200 nationally certified EMT-Basics and over 67,000 nationally certified Paramedics in the United States. ${ }^{10}$

\subsection{Occupational Health and Exposure in EMS}

EMS professionals' work environment is constantly changing. They respond to residential homes, highways, industrial settings, prisons, offices, and public areas. They respond day or night, and in any environmental condition. As such, each emergency presents with its own unique occupational exposures. Further, many occupational health problems are prevalent in EMS and will be discussed briefly.

When EMS professionals respond to an emergency, they often utilize lights and sirens. In 2004, a study was conducted to determine work-life characteristics associated with ambulance crashes. ${ }^{11}$ It was found that $9 \%$ of subjects had been involved in an 
ambulance crash, and of those, self-reported sleep problems was a statistically significant predictor of an ambulance crash. ${ }^{11}$ Likewise, after arrival to an emergency scene, these professionals may be exposed to situations that increase the likelihood of back injuries. ${ }^{12}$ These situations may include performing CPR, and lifting and moving both heavy equipment (such as stretchers) and patients. ${ }^{12}$ In a study conducted utilizing a national cohort of EMS professionals, back injury prevalence was found to be just over $18 \%{ }^{13}$

Violence and exposure to communicable diseases are additional occupational hazards in the prehospital emergency setting. Violence may be especially common when caring for patients with some medical and traumatic injuries, as well as patients under the influence of drugs and/or alcohol. A descriptive study in 1998 found that over $61 \%$ of EMS professionals self-reported being involved in an assault while working, and of those, $25 \%$ reported an injury. ${ }^{14}$ Likewise, while caring for patients, EMS professionals may be exposed to communicable diseases such as human immunodeficiency virus, hepatitis, and tuberculosis. ${ }^{15}$

In 2007, the one-year incidence of job-related injury and illness was found to be 8.1 per 100 in this occupation. ${ }^{16}$ This incidence was found to be statistically related to the number of calls the EMS professional responded to in a typical week, a previous history of back problems, and working in an urban versus rural environment. ${ }^{16}$ When this job-related injury and illness incidence is compared to other professions such as police and sheriff's officers (6.03 per 100), nursing aides, orderlies and attendants (4.56 per $100)$, and construction laborers (3.82 per 100), the EMS profession appears to have higher on the job illness and injuries. ${ }^{17}$ Further studies have also indicated high overall 
occupational injury rates among EMT-Basics and Paramedics. ${ }^{18}$ Taking the above into consideration, on-the-job injury and illness are problems in the EMS profession. This burden of injury and illness causes some EMS professionals not being able to fulfill their duties, which may impact public health from both the standpoint of worker health and the well being of the public served.

EMS professionals are not only exposed to a multitude of physical and environmental exposures but are also vulnerable to emotional exposures. Emotional exposures and related illness among EMS professionals will be discussed in the following sections.

\subsection{Mental Health Disease Burden}

According to the Surgeon General, mental health is defined as "a state of successful performance of mental function, resulting in productive activities, fulfilling relationships with other people, and the ability to adapt to change and to cope with adversity.",19 Likewise, mental illness is defined as "a collective term to describe all diagnosable mental disorders." ${ }^{19}$ In 1996, mental disorders were found to account for just over 15\% of the overall burden of disease from all causes in the United States. ${ }^{20}$ This estimate may be grossly underestimated as it has been reported that almost two-thirds of all people with mental disorders do not seek treatment. ${ }^{21,22}$ For the purposes of this study, three mental disorders will be discussed: depression, anxiety, and stress. 


\subsubsection{Depression}

According the Center for Disease Control and Prevention (CDC), one out of every 10 adult Americans currently report depression. ${ }^{23}$ Depression is a mood disorder that is characterized by dysphoria, sadness, anxiety, withdrawal, hopelessness, despair, loss of

sleep or excessive need for sleep, and possible exaggerated guilt feelings or thoughts. ${ }^{24-26}$ If the above characterizations affect psychological, physical, or interpersonal function for at least two weeks, a depression diagnosis may be given. ${ }^{24}$ Physical signs and symptoms of depression include headache, changes in appetite, loss of energy, and gastrointestinal disturbances. Intellectual symptoms may include slowed thinking, indecisiveness, poor concentration, and impaired memory. ${ }^{24}$

There is no single cause for depression. Predictors of depression include age, race, gender, education level, and marital status. ${ }^{23}$ Further, it may be related to many factors including past family history and psychosocial stressors. ${ }^{24,25}$ Included among $^{2}$ these psychosocial stressors are death of a spouse, employment loss, and possibly urban living. ${ }^{24}$ Not surprisingly, changes in one's own environment can play a role in the development of depression. This environmental change may include sudden changes in one's external environment, or any major loss. ${ }^{24,25}$

\subsubsection{Anxiety}

In a survey conducted by the National Institute of Mental Health, the prevalence of anxiety disorder was found to be $8.3 \%{ }^{24}$ Further, in the United States, generalized anxiety disorders affect 6.8 million adults. ${ }^{24}$ This number may be underestimated as 
anxiety disorders often present with physical symptoms and the psychological components often go unrecognized. ${ }^{24}$

Anxiety can be prompted by a combination of physical and environmental factors. $^{24,25}$ Anxiety can be marked by feelings of uneasiness, tension and apprehension. $^{24}$ Physical signs and symptoms can include increased heart rate, blood pressure, and respiratory rate, sweating, difficulty swallowing, dizziness, and chest pain. ${ }^{24}$ Because anxiety may be so debilitating, some individuals may turn to smoking, and alcohol and/or drug abuse. ${ }^{24}$

\subsubsection{Stress}

Stress is an internal response to stressors. ${ }^{24}$ Stressors can include interactions in difficult times, feeling inadequate at what one is doing, feeling trapped, and major losses in ones life. ${ }^{24}$ When a stressor is introduced, the amount of stress that is felt is related to the ability to adapt to the stressor itself. ${ }^{24}$ Adaptation to job stressors can be affected by characteristics such as age, stressors from personal life, and support systems. ${ }^{27}$ When these job stressors affect the individuals physiological and psychological balance, job strain can occur. ${ }^{27}$ Job strain is believed to lead to many adverse health conditions including, but not limited to, psychological disorders and cardiovascular disease. ${ }^{27}$ Individuals exposed to extreme stressors, such as witnessing a traumatic event or living through a natural disaster may develop patterns of stress known as post-traumatic stress disorder. $^{24}$

Stress disorder can be characterized by feelings of extreme withdrawal, helplessness, dissociative states, and anxiety. ${ }^{28}$ Physical symptoms include increased 
heart rate, blood pressure, and respiratory rate; chest pain; nausea; and tremors or shaking. ${ }^{24}$ Behavioral symptoms may also be present, including difficulty in making decisions, inability to concentrate, increased anger, and loss of appetite or overeating. ${ }^{24,29}$

\subsection{Occupational Exposures Related to Mental Health}

Mental trauma can be defined as "extreme or severe events that are so powerful, harmful, and threatening that they demand extraordinary coping efforts. ${ }^{, 30}$ Because of the unpredictable nature of their work, EMS professionals may be exposed to traumatic events at anytime. ${ }^{31-36}$ These events may include, but are not limited to, death of a child, abuse of a child or an elderly patient, murders, suicides, dangerous responses, knowing the patient, and natural or manmade disasters. It has been previously noted that EMT-B's and Paramedics are at high risk for exposure to mentally demanding situations. ${ }^{33}$ When EMS professionals were asked to describe the worst incident they had responded to, the most common exposure was related to pain, suffering, and death; and among the most stressful were incidents involving children. ${ }^{37,38}$ Reflecting on natural and manmade disasters, previous studies have indicated that post-disaster, psychological disorders are relatively common. ${ }^{39-41}$ It has also been noted that intrusive memories of the above types of incidents are common in EMS professionals. ${ }^{37}$ Further, in a study conducted by Regehr et al., 100\% $(n=86)$ of Paramedics had been involved in a traumatic event. ${ }^{31}$ In this qualitative study, one paramedic was noted as saying:

"I thought it was the child's father that had done this and I sat, just outside the building for the longest time just trying to make sense of it and of course that's the biggest trap in any of these things, trying to make sense of what are by definition nonsensical things. ",31 
During these events, EMS professionals must maintain their focus and their ability to function in giving quality patient care. ${ }^{31,42}$

\subsection{Effects of Occupational Exposures to Traumatic Events}

Exposure to traumatic events can affect both the mental and physical health of the EMS

professional. $^{42,43}$ During and after a traumatic event, EMS professionals may experience multiple physiological effects, including increased heart rate and blood pressure, nausea, muffled hearing, muscle tension, and metabolic disturbances. ${ }^{44}$ In one qualitative study, emergency workers described their traumatic stress reaction symptoms to include hypervigilance, flashbacks, insomnia, and physical upsets. ${ }^{38}$

Scant literature is available regarding the prevalence and incidence of depression and anxiety in the EMS population. Although minimal, extant studies show the importance of future research in this area. After September 11, 2001 search and rescue workers demonstrated a two- to three-fold increase in the prevalence of depression, anxiety, and panic when compared to the general population. ${ }^{45}$ It has also been noted that female EMS providers are more likely than males' to present with symptoms of depression. $^{46}$

Occupational stress has been shown to be a predictor of increased symptoms of depression. ${ }^{32}$ EMS professionals can experience three types of stress when involved in a traumatic event. ${ }^{47}$ The first is being reminded of one's own mortality. ${ }^{47}$ The second main stressor an EMS professional may experience is identifying with their patients. For example, if a critically ill or injured patient is of the same gender, race, and age of the 
EMS professionals, this may adversely affect the amount of stress felt. ${ }^{47}$ The third main stressor relates to large scale incidents and role ambiguity, such as not knowing their specific roles in large search and rescue incidents. ${ }^{47}$ It is believed that stress can affect an EMS professional's performance of prehospital care. ${ }^{48,49}$ In an early study conducted by Hammer et al., EMS professionals were found to project negative attitudes towards their patients due to stress. ${ }^{49}$ These negative attitudes included both trivializing a patient's complaints and making inaccurate diagnoses. ${ }^{49}$ Interestingly, it was found that EMS professionals remaining in the field became "stress resistant" as their experience in years increased. ${ }^{48}$ Again, after the terrorist attack of September 11, 2001, World Trade Center rescue workers were found to have a seventeen fold increase in stress-related incidents. ${ }^{50}$

Unfortunately, the effects of occupational exposure to traumatic events may have lasting impacts, and these effects may go untreated. ${ }^{46}$ It has previously been demonstrated that up to $69 \%$ of EMS professionals have never had enough time to recover emotionally between traumatic events. ${ }^{51}$ Further, one EMS-focused study indicated a nine-fold increase in alcohol use, a 12-fold increase in mental health stress leave, and a four-fold increase in psychiatric medication use after a traumatic event. ${ }^{31}$ In a 1998 study, it was found that EMS Professionals in the United Kingdom had a higher rate of early retirement because of both mental and physical illness when compared to other healthcare professionals. ${ }^{52}$ As such, research into depression, anxiety, and stress of EMS professionals is demonstrably needed. 


\subsection{Study Objectives and Hypotheses}

As briefly discussed above, occupational exposures related to physical illness and injury have been well described in the EMS profession. However, occupational exposures in the mental illness literature are not well-represented. Currently, no literature exists examining the prevalence of mental illness in a large national cohort of EMS professionals. As such, the purpose of this study was to address the lack of scientific knowledge and evidence in the field of mental illness among this population.

The objectives of this master's thesis are three fold. The first objective was to estimate the prevalence and severity of depression, anxiety, and stress among a cohort of nationally certified EMS professionals. Because other healthcare professions may have similar occupational exposures related to mental illness, the second objective of this study was to compare nationally certified EMS professional's depression, anxiety, and stress prevalence to other healthcare professions. The third objective of this master's thesis was to determine the differences between cases and controls (defined by the 21 questions Depression, Anxiety, and Stress Scale (DASS-21)) from the same cohort with respect to clinical depression, anxiety, and stress and demographic and work-life characteristics.

For the purposes of the current study, independent demographic and work-life characteristic variables were chosen based on plausibility and past literature. Among EMS professionals, the prevalence of mental-disorders has been found to be associated with gender, age, race, marital status, certification level, experience level, size of EMS organization, call volume, smoking status and community size. ${ }^{32,33,38,43,44,46,48,53}$ It is 
believed that certification level may be related to a higher likelihood for stress because those with an EMT-Basic certification may not have the skills and training to care for critically sick or injured patients. ${ }^{53}$ Likewise Paramedics face the challenges of caring for critically sick or injured patients in emergent settings. ${ }^{53}$ Experience level may be explained due to EMS professionals' becoming accustomed and adapted to the stress and demands of the profession. ${ }^{38,48,53}$ However, higher experience level has also been described as a predictor of an increase in the severity of response to traumatic events. ${ }^{32,38}$ Further, it is thought that community size may be related to an EMS professional's stress level due to resources available. ${ }^{53}$ Smaller, more rural EMS systems may lack the funding for additional equipment and personnel when compared to larger urban systems. ${ }^{53}$ Call volume has also been found to be a predictor of increased reaction to traumatic events. This is thought to be due to the fact that more emergent care given to patients increases the chances of being involved in a traumatic event. ${ }^{38}$

The second objective of this study focuses on the prevalence of depression, anxiety, and stress of EMS professional's when compared to other healthcare professionals. It is hypothesized that EMS professionals will have a higher prevalence of depression, anxiety, and stress when compared to other healthcare professions. This is believed to be true because the EMS system is on the frontline of emergency care and many of the traumatic events never make it within hospital walls; thus EMS professionals are exposed more often to incidents that may cause depression, anxiety, and stress.

The third objective focuses on demographic and work-life characteristics as possible predictors of clinical depression, anxiety, and stress among EMS professionals. It is hypothesized that there will be demographic and work-life characteristics associated with 
depression, anxiety, and stress among nationally certified EMS professionals. Evidence from the literature supports this hypothesis, as well as the concept that increased occupational exposure may lead to depression, anxiety, and stress. ${ }^{32,33,38,43,44,46,48,53}$ This is believed to be true because as levels of certain variables increase, such as call volume, community size, and certification level, the number of emergent calls and the critically sick or injured patients of those calls also increase.

\subsection{Summary}

Currently, the levels of mental health among EMS professionals' are largely unknown on a national scale. Because EMS professionals are on the frontline of emergency care, it is of utmost importance to ensure that both their physical and mental health are understood and safeguarded. Toward that end, this master's thesis aims to address the status of mental health among EMS professionals on a national level. To accomplish this, three objectives are addressed: (1) estimation of the prevalence and severity of depression, anxiety, and stress among a cohort of nationally certified EMS professionals; (2) comparison of EMS professionals' depression, anxiety, and stress prevalence to other healthcare professions; and (3) estimation of differences in demographic and work life characteristics between cases and controls from the same cohort (defined by the DASS-21) with respect to clinical depression, anxiety, and stress. 


\section{Chapter 2: Materials and Methods}

\subsection{EMS Recertification Process}

In 1969, President Lyndon Johnson's Committee on Highway Traffic Safety

recommended the creation of a national EMS certification agency. ${ }^{54}$ It was recognized that a need existed for uniform standards and training for all EMS professionals across the United States. ${ }^{54}$ This recommendation resulted in the formation of the National Registry of Emergency Medical Technicians (NREMT) which is currently the nation's EMS certification body. ${ }^{54}$

In the United States, national certification is utilized by 44 states to issue an initial state license to practice, whereas only 8 states utilize national certification for state recertification. ${ }^{3}$ Once initial national certification is earned, biannual recertification is required to maintain a national standing. ${ }^{7,8}$ In October of every year, the NREMT mails a packet of recertification paperwork to those EMS professionals whose national certification will expire that upcoming March. Even if not required to do so by their state, many EMS professionals maintain national certification. Within this recertification paperwork, a research questionnaire may be found. 


\subsection{Data Source}

In accordance with previous studies, a questionnaire was included as part of the 2009 biennial recertification paperwork mailed to all nationally-certified EMS

professionals prior to their 2009 expiration date. ${ }^{55-59}$ This questionnaire contained demographic and work-life characteristic items as well as the Depression, Anxiety, and Stress-21 question scale (DASS-21) [Appendix A]. Participation in the current study was fully voluntary and had no bearing on recertification status. There was no incentive to participate, and the survey instrument took no longer than 10 minutes to complete. EMS professionals receiving their recertification paperwork were explained their rights as a study participant, and were asked to return their survey instrument inside a selfaddressed, stamped envelope, along with their recertification paperwork.

Previous demographic and work-life characteristic variables were used on the current questionnaire, as well as variables that related to depression, anxiety, and stress. Further, the DASS-21 was included to assess clinical depression, anxiety, and. The psychometric properties and validity of the DASS-21 will be discussed later. Cognitive debriefing protocol was developed and the instrument was pilot-tested among EMS professionals. Changes to the questionnaire were implemented where needed.

Data for the present study were collected between October 2008 and March 2009. Upon receiving an individual's recertification paperwork, NREMT staff separated the research questionnaire, thereby completely removing any personal identifiers, and delivered only that questionnaire to the research department. Questionnaires were 
scanned using a National Computer Systems optical scanner [National Computer Systems, North Brunswick, NJ]. The results were then moved into a Microsoft Access Database [Microsoft Corp., Redmond, WA].

\subsection{Variable Description}

There were three outcome variables of interest: clinical depression, clinical anxiety, and clinical stress. These outcome variables were assessed by using the DASS-21. Any scores higher than "normal" for each of the outcomes were classified a case. Afterwards, a case-control analysis was performed for each of the three outcome variables. Independent variables were chosen based on previous studies and plausibility. A total of 15 independent predictor variables were assessed.

\subsubsection{Demographic Variables}

A total of nine demographic variables were assessed, including: gender (male and female), age (as a continuous variable), race (American Indian or Alaska Native, Asian, Black or African American, Hispanic or Latino, Native Hawaiian or Other Pacific Islander, and White), education level (Didn't complete high school, High school graduate/GED, Some college, Associate's Degree, Bachelor's Degree, and Graduate Degree), marital status (Married, Divorced, Widowed, Separated, A member of an unmarried couple, and Never been married), self-reported health status (Excellent, Very Good, Good, Fair, Poor), Body Mass Index (analyzed as a continuous variable and calculated by dividing 703 times self-reported weight in pounds by self-reported height in square inches), self-reported exercise in the past month (Yes, No, Don't know), and 
smoking status. Current smoking status was classified by answering yes to the question "Have you smoked at least 100 cigarettes in your entire life?" and reported "every day or "some days" when asked "Do you now smoke cigarettes every day, some days, or not at all?" Those classified as non-smokers answered "No" and "Not at all" to the above questions, respectively. Lastly, those individuals who self-reported smoking at least 100 cigarettes in their entire life and self-reported "Not at all" for the questions "Do you now smoke cigarettes every day, some days, or not at all" were classified as former smokers.

In order to achieve a more parsimonious multivariable model and to increase cell sizes, the variables pertaining to race, education level, marital status, and self-reported exercise were collapsed as follows. Race was dichotomized into "Non-minority" (White) and "Minority" (American Indian or Alaska Native, Asian, Black or African American, Hispanic or Latino, Native Hawaiian or Other Pacific Islander). Education level was dichotomized into "Less than a college degree" (Didn’t complete high school, High school graduate/GED, Some college) and "College degree" (Associate's Degree, Bachelor's Degree, Graduate Degree). Marital status was combined into three variables; "Married", "Divorced/Widowed/Separated" and "Never been married" (A member of an unmarried couple, Never been married). Self-reported exercise was conservatively dichotomized into "Yes" and "No" (combining the responses of "No" and "Don't know"). Table 1 shows the final variables utilized for this study.

\subsubsection{Occupational Characteristics}

A total of five occupational characteristics were assessed. These included certification level (First Responder, EMT-Basic, EMT-Intermediate, EMT-paramedic, Temporarily 
not practicing, and Permanently not practicing), community size in which primary EMS work was conducted (Rural Area (less than 2,500 people), Small Town (2,500-24,999 people) Medium Town (25,000-74,999 people), Large Town (75,000-149,999 people), Mid-sized city (less than 500,000 people), Suburb/Fringe of a mid-sized city, Large City (500,000 or more people), and Suburb/Fringe of a large city), EMS service type (FireBased, County or Municipal, Private, for profit, Private, not for profit, Hospital-based, U.S. Federal Government (non-military), Military, I am not affiliated with any organization, and Other), years of experience in EMS (I am not an EMT, Less than one year, 1-2 years, 3-4 years, 5-7 years, 8-10 years, 11-15 years, 16-20 years, and 21 or more years), and call volume in a typical week ( $0,1,2$ to 4,5 to 9,10 to 19,20 to 29,30 to 39 , 40 to 49,50 or more).

In order to assure a more parsimonious model and to increase cell sizes, certification level, community size, service type, experience, and call volume were collapsed. For the purposes of the current study, only EMT-Basics and Paramedics were included in the analysis. This decision was based on the complexity of certification levels across each state and EMT-Basic and Paramedic certification levels are the only nationally recognized level across all states. Therefore, in the certification level variable, First Responders, EMT-Intermediates, Temporarily not practicing, and Permanently not practicing were removed from the data set. Community size was dichotomized into "small" ( $<25,000$ people) and "large" ( $>=25,000$ people). Service type was collapsed to "Fire-Based", "County or Municipal", "Private" (Private, for profit, Private, not-for-profit), "Hospital-Based", and "Other" (U.S. Federal Government (non- 
military), Military, I am not affiliated with any organization, and Other). Years of EMS experience was collapsed into " $<1$ year", "1-4 years", "5-10 years", and "> $>10$ years". Call volume was collapsed into "low" (0-9 runs per week), "medium" (10-39 runs per week), and "high" ( $>40$ runs per week). Table 1 shows the final variables utilized for this study.

\begin{tabular}{|c|l|}
\hline \multicolumn{2}{|l|}{ Demographic Variables } \\
\hline Gender & $\begin{array}{l}\text { Male } \\
\text { Female }\end{array}$ \\
\hline Age & Analyzed as Continuous Variable \\
\hline Race & $\begin{array}{l}\text { Non-Minority } \\
\text { Minority }\end{array}$ \\
\hline Education Level & $\begin{array}{l}\text { Less than a college degree } \\
\text { College Degree }\end{array}$ \\
\hline Marital Status & $\begin{array}{l}\text { Married } \\
\text { Divorced/Widowed/Separated } \\
\text { Never Been Married }\end{array}$ \\
\hline Health Status & $\begin{array}{l}\text { Excellent } \\
\text { Very Good } \\
\text { Good, Fair/Poor }\end{array}$ \\
\hline Body Mass Index & Analyzed as Continuous Variable \\
\hline Exercise in Past Month & $\begin{array}{l}\text { Yes } \\
\text { No/Don't Know }\end{array}$ \\
\hline Smoking Status & $\begin{array}{l}\text { Current Smokers } \\
\text { Former Smokers } \\
\text { Non-Smokers }\end{array}$ \\
\hline
\end{tabular}

Continued

Table 1. Variable Description 
Table 1 Continued

\begin{tabular}{|c|l|}
\hline \multicolumn{2}{|l|}{ Occupational Characteristics } \\
\hline Certification Level & $\begin{array}{l}\text { EMT-Basic } \\
\text { Paramedic }\end{array}$ \\
\hline Community Size & $\begin{array}{l}\text { Small }(<25,000 \text { people) } \\
\text { Large }(\geq 25,000 \text { people) }\end{array}$ \\
\hline \multirow{5}{*}{ Service Type } & Fire-Based \\
& County or Municipal \\
& Private \\
& Hospital-Based \\
& Other \\
\hline \multirow{5}{*}{ Years of Experience } & $<1$ Year \\
& $1-4$ Years \\
& $5-10$ Years \\
& $>10$ Years \\
\hline \multirow{2}{*}{ Call Volume } & Low (0-9 runs) \\
& Medium (10-39 runs) \\
& High ( $>40$ runs) \\
\hline
\end{tabular}

\subsubsection{Depression, Anxiety, and Stress 21-Question Scale}

The DASS-21 consists of three self-reported scales designed to measure clinical levels of depression, anxiety, and stress. ${ }^{60}$ Seven questions are asked in each category about symptoms experienced over the past week and are scored on a four point scale (Did not apply to me at all=0, Applied to me to some degree, or some of the time $=1$, Applied to me to a considerable degree, or a good part of the time $=2$, Applied to me very much, or most of the time=3). (Appendix A). ${ }^{60}$ To determine the clinical level of each outcome (depression, anxiety, and stress), the scores for each category are totaled and multiplied by two (Appendix B). Psychometric properties of the DASS-21 indicate high reliability and high convergent validity. Multiple studies have shown Cronbach's alpha levels above 0.8 for each of the depression, anxiety, and stress scales as well as the scale in 
total. $^{61-66}$ Likewise, when compared to other validated measures of depression and anxiety, the DASS-21 is highly correlated indicating high convergent validity. ${ }^{61-67}$

\subsection{Analysis Plan}

To meet the first objective of estimating the prevalence and severity of depression, anxiety, and stress among a cohort of nationally certified EMS professionals, each outcome variable (clinical depression, clinical anxiety, and clinical stress) was determined using the DASS-21. After estimation of the prevalence of the outcomes, a detailed literature search was conducted to compare the prevalence of depression, anxiety, and stress among nationally certified EMS professionals' to other healthcare professions to meet the second objective of this study.

The third objective was to compare and contrast cases and controls with respect to depression, anxiety, and stress. Summary statistics were calculated to describe the population and to identify possible associations for each of the outcome variables. Univariate Odds Ratios (OR's) were calculated for each outcome variable and each independent variable to assess possible associations between independent variables and the outcomes. These data were analyzed with STATA version 9 (College Station, TX).

For each outcome variable, a multivariable logistic regression model was built. An investigator controlled backwards selection method was utilized to identify significant variables related to each outcome. Variables were eliminated from the model based on Wald p-values $>0.05$. After removal of each variable, a maximum likelihood ratio test was performed to determine if the individual variable was significant in the model. For each model, effect modification was assessed using plausible interaction terms. Because 
the backwards selection process was utilized, interaction terms were introduced into the model first. If the interaction term was significant, both of the individual variables were forced into the model. Confounding was assessed by calculating a percentage change in outcome by removal of each independent variable. If a $10 \%$ or greater change was observed, that variable was classified as a confounder and was kept in the model. Each model's fit was assessed utilizing the Hosmer-Lemeshow goodness of fit test. 


\section{Chapter 3: Results}

\subsection{Analysis of Missing Data}

To assess possible item-non response bias, an analysis of missing data was conducted before analyses of the current dataset. It was found that 5,058 (14.7\%) individuals had not responded to at least one of the independent variables. Of those, an average of 2.04 items was missed. When individuals with missing data were compared to the outcome of depression, no statistical significance was found $(\mathrm{p}=0.555)$. Likewise, when the same individuals were compared with the outcome of clinical anxiety and clinical stress, no statistical significance was found $(p=0.699, p=0.665$, respectively). Therefore, because there was no evidence of item non-response bias, all missing data were removed from analyses, leaving 29,282 individuals for analyses.

\subsection{Descriptive Analysis}

A total of 64,032 individuals chose to recertify and 34,340 (53.6\%) returned a questionnaire. There were 1,589 (6.8\%) nationally certified EMS professionals determined to be clinically depressed according to the DASS-21. There were 1,406 $(6.0 \%)$ of nationally certified EMS professionals who were determined to be anxious. Lastly, there were 1,382 (5.9\%) of EMS professionals classified as stressed. Further, 420 $(1.8 \%)$ individuals were found to be depressed, anxious, and stressed. There were 309 $(1.3 \%)$ EMS professionals found to be both depressed and stressed, 249 (1.1\%) found to 
be both depressed and anxious, and $195(0.8 \%)$ found to be both anxious and stressed. Likewise, 611 (2.6\%) of EMS

professionals were found to be solely depressed, $542(2.3 \%)$ were only anxious, and 458 $(1.9 \%)$ were found to be only stressed.

The severity of depression, anxiety, and stress may be found in Table 1. For those individuals above normal $(93.2 \%)$ in depression, the highest category was mild $(3.5 \%)$, followed by moderate $(2.4 \%)$, severe $(0.5 \%)$, and extremely severe $(0.4 \%)$. In those EMS professionals scoring above normal in anxiety, moderate anxiety $(2.7 \%)$ was the most common followed by mild $(2.5 \%)$, severe $(0.5 \%)$, and extremely severe $(0.3 \%)$. Lastly, of those scoring above a normal stress level, mild stress $(3.1 \%)$ was the most common followed by moderate $(1.9 \%)$, severe $(0.7 \%)$, and extremely severe $(0.1 \%)$.

\begin{tabular}{|l|c|c|c|}
\hline & Depression & Anxiety & Stress \\
\hline Normal & $21,862(93.2 \%)$ & $22,045(94.0 \%)$ & $22,069(94.1 \%)$ \\
\hline Mild & $822(3.5 \%)$ & $579(2.5 \%)$ & $729(3.1 \%)$ \\
\hline Moderate & $555(2.4 \%)$ & $628(2.7 \%)$ & $464(1.9 \%)$ \\
\hline Severe & $122(0.5 \%)$ & $116(0.5 \%)$ & $155(0.7 \%)$ \\
\hline Extremely Severe & $90(0.4 \%)$ & $83(0.3 \%)$ & $34(0.1 \%)$ \\
\hline
\end{tabular}

Table 2. Severity of Depression, Anxiety, and Stress 


\subsubsection{Depression}

Table 3 presents descriptive statistics for all categorical variables. Table 4 presents descriptive statistics for all continuous variables.

\begin{tabular}{|c|c|c|c|c|}
\hline & $\begin{array}{c}\text { Total } \\
\text { Sample }\end{array}$ & Depressed & $\begin{array}{c}\text { Non- } \\
\text { Depressed }\end{array}$ & $\begin{array}{c}\text { Univariable OR } \\
(95 \% C I)\end{array}$ \\
\hline & $\mathrm{n}(\%)$ & $\mathrm{n}(\%)$ & $\mathrm{n}(\%)$ & \\
\hline \multicolumn{5}{|l|}{ Certification Level } \\
\hline EMT-Basic & $\begin{array}{c}12,212 \\
(52.07 \%)\end{array}$ & $\begin{array}{c}542 \\
(4.44 \%)\end{array}$ & $\begin{array}{c}11,670 \\
(95.56 \%)\end{array}$ & Referent \\
\hline Paramedic & $\begin{array}{c}11,239 \\
(47.93 \%)\end{array}$ & $\begin{array}{c}1,047 \\
(9.32 \%)\end{array}$ & $\begin{array}{c}10,192 \\
(90.68 \%)\end{array}$ & $\begin{array}{c}1.49 \\
(1.41-1.57)\end{array}$ \\
\hline \multicolumn{5}{|l|}{ Community Size } \\
\hline Small $(<25,000$ people $)$ & $\begin{array}{c}9,202 \\
(39.24 \%)\end{array}$ & $\begin{array}{c}591 \\
(6.42 \%)\end{array}$ & $\begin{array}{c}8,611 \\
(93.58 \%)\end{array}$ & Referent \\
\hline Large ( $\geq 25,000$ people) & $\begin{array}{c}14,249 \\
(60.76 \%) \\
\end{array}$ & $\begin{array}{c}998 \\
(7.00 \%) \\
\end{array}$ & $\begin{array}{c}13,251 \\
(93.00 \%) \\
\end{array}$ & $\begin{array}{c}1.10 \\
(0.99-1.22) \\
\end{array}$ \\
\hline \multicolumn{5}{|l|}{ Service Type } \\
\hline Fire-Based & $\begin{array}{c}8,544 \\
(36.43 \%)\end{array}$ & $\begin{array}{c}458 \\
(5.36 \%)\end{array}$ & $\begin{array}{c}8,086 \\
(94.64 \%)\end{array}$ & Referent \\
\hline County or Municipal & $\begin{array}{c}3,107 \\
(13.25 \%) \\
\end{array}$ & $\begin{array}{c}277 \\
(8.92 \%) \\
\end{array}$ & $\begin{array}{c}2,830 \\
(91.08 \%) \\
\end{array}$ & $\begin{array}{c}1.73 \\
(1.48-2.02) \\
\end{array}$ \\
\hline Private & $\begin{array}{c}4,873 \\
(20.78 \%) \\
\end{array}$ & $\begin{array}{c}440 \\
(9.03 \%) \\
\end{array}$ & $\begin{array}{c}4,433 \\
(90.97 \%) \\
\end{array}$ & $\begin{array}{c}1.75 \\
(1.53-2.01) \\
\end{array}$ \\
\hline Hospital-Based & $\begin{array}{c}2,470 \\
(10.53 \%) \\
\end{array}$ & $\begin{array}{c}228 \\
(9.23 \%) \\
\end{array}$ & $\begin{array}{c}2,242 \\
(90.77 \%)\end{array}$ & $\begin{array}{c}1.79 \\
(1.52-2.12) \\
\end{array}$ \\
\hline Other & $\begin{array}{c}4,457 \\
(19.01 \%)\end{array}$ & $\begin{array}{c}186 \\
(4.17 \%)\end{array}$ & $\begin{array}{c}4,271 \\
(95.83 \%)\end{array}$ & $\begin{array}{c}0.77 \\
(0.64-2.12)\end{array}$ \\
\hline \multicolumn{5}{|l|}{ Experience } \\
\hline$\leq 2$ Years & $\begin{array}{c}3,410 \\
(14.54 \%)\end{array}$ & $\begin{array}{c}168 \\
(4.93 \%)\end{array}$ & $\begin{array}{c}3,242 \\
(95.07 \%)\end{array}$ & Referent \\
\hline 3-7 Years & $\begin{array}{c}7,445 \\
(31.75 \%)\end{array}$ & $\begin{array}{c}374 \\
(5.02 \%)\end{array}$ & $\begin{array}{c}7,071 \\
(94.89 \%)\end{array}$ & $\begin{array}{c}1.02 \\
(0.85-1.23)\end{array}$ \\
\hline 8-15 Years & $\begin{array}{c}7,269 \\
(31.00 \%) \\
\end{array}$ & $\begin{array}{c}555 \\
(7.64 \%) \\
\end{array}$ & $\begin{array}{c}6,714 \\
(92.36 \%) \\
\end{array}$ & $\begin{array}{c}1.59 \\
(1.33-1.90) \\
\end{array}$ \\
\hline$\geq 16$ Years & $\begin{array}{c}5,327 \\
(22.72 \%) \\
\end{array}$ & $\begin{array}{c}492 \\
(9.24 \%) \\
\end{array}$ & $\begin{array}{c}4,835 \\
(90.76 \%) \\
\end{array}$ & $\begin{array}{c}1.96 \\
(1.64-2.35) \\
\end{array}$ \\
\hline
\end{tabular}

Continued

Table 3. Depression Summary Statistics for Categorical Variables 
Table 3 continued

\begin{tabular}{|c|c|c|c|c|}
\hline \multicolumn{5}{|l|}{ Call Volume } \\
\hline Low ( $0-9$ calls $)$ & $\begin{array}{c}11,747 \\
(50.09 \%)\end{array}$ & $\begin{array}{c}643 \\
(5.47 \%)\end{array}$ & $\begin{array}{c}11,104 \\
(94.53 \%)\end{array}$ & Referent \\
\hline Moderate (10-39 calls) & $\begin{array}{c}10,333 \\
(44.06 \%) \\
\end{array}$ & $\begin{array}{c}838 \\
(8.11 \%) \\
\end{array}$ & $\begin{array}{c}9,495 \\
(91.89 \%) \\
\end{array}$ & $\begin{array}{c}1.52 \\
(1.37-1.69) \\
\end{array}$ \\
\hline High $(40+$ calls $)$ & $\begin{array}{c}1,371 \\
(5.85 \%) \\
\end{array}$ & $\begin{array}{c}108 \\
(7.88 \%) \\
\end{array}$ & $\begin{array}{c}1,263 \\
(92.12 \%) \\
\end{array}$ & $\begin{array}{c}1.48 \\
(1.48-1.82) \\
\end{array}$ \\
\hline \multicolumn{5}{|l|}{ Race } \\
\hline Non-Minority & $\begin{array}{c}19,930 \\
(84.99 \%) \\
\end{array}$ & $\begin{array}{c}1,416 \\
(7.10 \%) \\
\end{array}$ & $\begin{array}{c}18,514 \\
(92.90 \%) \\
\end{array}$ & Referent \\
\hline Minority & $\begin{array}{c}3,521 \\
(15.01 \%) \\
\end{array}$ & $\begin{array}{c}173 \\
(4.91 \%) \\
\end{array}$ & $\begin{array}{c}3,348 \\
(95.09 \%) \\
\end{array}$ & $\begin{array}{c}0.67 \\
(0.57-0.79) \\
\end{array}$ \\
\hline \multicolumn{5}{|l|}{ Education } \\
\hline $\begin{array}{l}\text { Less than a College } \\
\text { Degree }\end{array}$ & $\begin{array}{c}12,964 \\
(55.28 \%) \\
\end{array}$ & $\begin{array}{c}862 \\
(6.65 \%) \\
\end{array}$ & $\begin{array}{c}12,102 \\
(93.35 \%) \\
\end{array}$ & Referent \\
\hline $\begin{array}{l}\text { College Degree or } \\
\text { Higher }\end{array}$ & $\begin{array}{c}10,487 \\
(44.72 \%) \\
\end{array}$ & $\begin{array}{c}727 \\
(6.93 \%) \\
\end{array}$ & $\begin{array}{c}9,760 \\
(93.07 \%) \\
\end{array}$ & $\begin{array}{c}1.04 \\
(0.94-1.15)\end{array}$ \\
\hline \multicolumn{5}{|l|}{ Gender } \\
\hline Male & $\begin{array}{c}17,326 \\
(73.88 \%) \\
\end{array}$ & $\begin{array}{c}1,200 \\
(6.93 \%) \\
\end{array}$ & $\begin{array}{c}16,126 \\
(93.07 \%) \\
\end{array}$ & Referent \\
\hline Female & $\begin{array}{c}6,125 \\
(26.12 \%) \\
\end{array}$ & $\begin{array}{c}389 \\
(6.35 \%) \\
\end{array}$ & $\begin{array}{c}5,736 \\
(93.65 \%) \\
\end{array}$ & $\begin{array}{c}0.91 \\
(0.81-1.02) \\
\end{array}$ \\
\hline \multicolumn{5}{|l|}{ Marital Status } \\
\hline Married & $\begin{array}{c}14,730 \\
(62.81 \%) \\
\end{array}$ & $\begin{array}{c}888 \\
(6.03 \%) \\
\end{array}$ & $\begin{array}{c}13,842 \\
(93.97 \%) \\
\end{array}$ & Referent \\
\hline $\begin{array}{l}\text { Divorced/Widowed/ } \\
\text { Separated }\end{array}$ & $\begin{array}{c}3,132 \\
(13.36 \%) \\
\end{array}$ & $\begin{array}{c}295 \\
(9.42 \%) \\
\end{array}$ & $\begin{array}{c}2,837 \\
(90.58 \%) \\
\end{array}$ & $\begin{array}{c}1.62 \\
(1.41-1.86) \\
\end{array}$ \\
\hline Never Been Married & $\begin{array}{c}5,589 \\
(23.83 \%) \\
\end{array}$ & $\begin{array}{c}406 \\
(7.26 \%) \\
\end{array}$ & $\begin{array}{c}5,183 \\
(92.74 \%) \\
\end{array}$ & $\begin{array}{c}1.22 \\
(1.08-1.38) \\
\end{array}$ \\
\hline \multicolumn{5}{|l|}{ General Health } \\
\hline Excellent & $\begin{array}{c}6,185 \\
(26.37 \%) \\
\end{array}$ & $\begin{array}{c}168 \\
(2.72 \%) \\
\end{array}$ & $\begin{array}{c}6,017 \\
(97.28 \%) \\
\end{array}$ & Referent \\
\hline Very Good & $\begin{array}{c}10,653 \\
(45.43 \%) \\
\end{array}$ & $\begin{array}{c}614 \\
(5.76 \%) \\
\end{array}$ & $\begin{array}{c}10,039 \\
(94.24 \%) \\
\end{array}$ & $\begin{array}{c}2.19 \\
(1.84-2.60) \\
\end{array}$ \\
\hline Good & $\begin{array}{c}6,207 \\
(26.47 \%) \\
\end{array}$ & $\begin{array}{c}686 \\
(11.05 \%) \\
\end{array}$ & $\begin{array}{c}5,521 \\
(88.95 \%) \\
\end{array}$ & $\begin{array}{c}4.45 \\
(3.74-5.29) \\
\end{array}$ \\
\hline Fair/Poor & $406(1.73 \%)$ & $\begin{array}{c}121 \\
(29.80 \%) \\
\end{array}$ & $285(70.20 \%)$ & $\begin{array}{c}15.20 \\
(11.69-19.76) \\
\end{array}$ \\
\hline
\end{tabular}

Continued 
Table 3 Continued

\begin{tabular}{|l|c|c|c|c|}
\hline \multicolumn{5}{|l|}{ Exercise in the Past Month } \\
\hline Yes & $\begin{array}{c}20,930 \\
(89.25 \%)\end{array}$ & $\begin{array}{c}1,216 \\
(5.81 \%)\end{array}$ & $\begin{array}{c}19,714 \\
(94.19 \%)\end{array}$ & Referent \\
\hline \multirow{2}{*}{ No } & 2,521 & 373 & 2,148 \\
$(10.75 \%)$ & $(14.80 \%)$ & $(85.20 \%)$ & $\begin{array}{c}2.81 \\
(2.49-3.19)\end{array}$ \\
\hline Smoking Status & 3,473 & 317 & 3,156 & Referent \\
\hline \multirow{2}{*}{ Never Smoker } & $(14.81 \%)$ & $(9.13 \%)$ & $(90.87 \%)$ & $\begin{array}{c}1.24 \\
\end{array}$ \\
Former/Ever Smoker & 4,877 & 361 & 4,516 & $(1.10-1.41)$ \\
\hline \multirow{2}{*}{ Current Smoker } & $(20.80 \%)$ & $(7.40 \%)$ & $(92.60 \%)$ & 1.56 \\
& $(64,101$ & 911 & 14,190 & $(1.37-1.79)$ \\
\hline
\end{tabular}

\begin{tabular}{|c|c|c|c|}
\hline & n (\%) & Mean (SD) & $\begin{array}{c}\text { Univariable OR } \\
(95 \% \mathrm{CI})\end{array}$ \\
\hline \multicolumn{4}{|l|}{ Age } \\
\hline Depressed & $1,589(6.78 \%)$ & 37.72 years $(10.30)$ & \multirow{3}{*}{$\begin{array}{c}1.01 \\
(1.00-1.01)\end{array}$} \\
\hline Non-Depressed & $21,862(93.22 \%)$ & 38.60 years $(9.86)$ & \\
\hline Total Population & & 37.78 years $(10.27)$ & \\
\hline \multicolumn{4}{|l|}{ BMI (lbs/inches $\left.{ }^{2}\right)$} \\
\hline Depressed & $1,589(6.78 \%)$ & $29.62 \mathrm{lbs} /$ inches $^{2}(6.38)$ & \multirow{3}{*}{$\begin{array}{c}1.05 \\
(1.04-1.06)\end{array}$} \\
\hline Non-Depressed & $21,862(93.22 \%)$ & $28.03 \mathrm{lbs} /$ inches $^{2}(5.12)$ & \\
\hline Total Population & & $28.14 \mathrm{lbs} /$ inches $^{2}(5.23)$ & \\
\hline
\end{tabular}

Table 4. Depression Summary Statistics for Continuous Variables

There were 11 independent variables that were statistically significant when compared to the dichotomous outcome of depression (Table 1 and Table 2). The odds of depression among Paramedics was 1.49 (95\% CI=1.41-1.57) times the odds of depression among EMT-Basics. With regards to EMS service type, when compared to EMS professionals working in a fire-based setting, those working in county or municipal services were 1.73 $(95 \% \mathrm{CI}=1.48-2.02)$ times as likely, those in private services were $1.75(95 \% \mathrm{CI}=1.53-$ 
2.01) times as likely, those in hospital-based services were $0.79(95 \% \mathrm{CI}=1.52-2.12)$ times as likely, and those in other services were $0.77(95 \% \mathrm{CI}=0.64-2.12)$ as likely to be depressed. When compared to two years or less of EMS experience, those with 3-7 years were $1.02(95 \% \mathrm{CI}=0.85-1.23)$ times as likely, $8-15$ years experience were $1.59(95 \%$ $\mathrm{CI}=0.33-1.90)$ times as likely, and those with $\geq 16$ years of experience were $1.96(95 \%$ $\mathrm{CI}=1.64-2.35$ ) times as likely to be depressed. The odds of depression among those EMS professionals a moderate call volume was $1.52(95 \% \mathrm{CI}=1.37-1.69)$ times the odds of depression among those working a low call volume. Further, the odds of depression among those working a high call volume was $1.48(95 \% \mathrm{CI}=1.19-1.82)$ the odds of depression among those working a low call volume. Race was also found to be a statistically significant predictor of depression with non-minority being referent and minority possibly being protective $(\mathrm{OR}=0.67,95 \% \mathrm{CI}=0.57-0.79)$. When compared to those EMS professionals who were married, those who were divorced/widowed/separated were $1.62(95 \% \mathrm{CI}=1.41-1.86)$ times as likely, and those who reported never being married were $1.22(95 \% \mathrm{CI}=1.08-1.38)$ times as likely to be depressed. Interestingly, a step-wise increase in the odds of being depressed was found when comparing selfreported health status. With those in excellent health being referent, those in very good health were $2.19(95 \% \mathrm{CI}=1.84-2.60)$ as likely, those in good health were $4.45(95 \%$ $\mathrm{CI}=3.74-5.29)$ as likely, and those in fair/poor health were $15.20(95 \% \mathrm{CI}=11.69-19.76)$ as likely to be depressed. The odds of depression among those EMS professionals who did not exercise in the past month was $2.81(95 \% \mathrm{CI}=2.49-3.79)$ times the odds of depression among those who did exercise. Another step-wise increase was found when 
comparing never smokers to former/ever smokers $(\mathrm{OR}=1.24,95 \% \mathrm{CI}=1.10-1.41)$ and current smokers $(\mathrm{OR}=1.56,95 \% \mathrm{CI}=1.37-1.79)$. Lastly, age $(\mathrm{OR}=1.01,95 \% \mathrm{CI}=1.00$ 1.01) and $\mathrm{BMI}(\mathrm{OR}=1.5,95 \% \mathrm{CI}=1.01-1.06)$ was found to be statistically significant with regards to depression.

\subsubsection{Anxiety}

Table 5 presents descriptive statistics for all categorical variables. Table 6 presents descriptive statistics for all continuous variables.

\begin{tabular}{|c|c|c|c|c|}
\hline & $\begin{array}{c}\text { Total } \\
\text { Sample }\end{array}$ & Anxious & $\begin{array}{c}\text { Non- } \\
\text { Anxious } \\
\end{array}$ & $\begin{array}{c}\text { Univariable OR } \\
(95 \% \mathrm{CI})\end{array}$ \\
\hline & $\mathrm{n}(\%)$ & $\mathrm{n}(\%)$ & $\mathrm{n}(\%)$ & \\
\hline \multicolumn{5}{|l|}{ Certification Level } \\
\hline EMT-Basic & $\begin{array}{c}12,212 \\
(52.07 \%)\end{array}$ & $\begin{array}{c}588 \\
(4.81 \%) \\
\end{array}$ & $\begin{array}{c}11,624 \\
(95.19 \%)\end{array}$ & Referent \\
\hline Paramedic & $\begin{array}{c}11,239 \\
(47.93 \%) \\
\end{array}$ & $\begin{array}{c}818 \\
(7.28 \%) \\
\end{array}$ & $\begin{array}{c}10,421 \\
(92.72 \%)\end{array}$ & $\begin{array}{c}1.24 \\
(1.18-1.31)\end{array}$ \\
\hline \multicolumn{5}{|l|}{ Community Size } \\
\hline Small $(<25,000$ people $)$ & $\begin{array}{c}9,202 \\
(39.24 \%)\end{array}$ & $\begin{array}{c}553 \\
(6.01 \%)\end{array}$ & $\begin{array}{c}8,649 \\
(93.99 \%)\end{array}$ & Referent \\
\hline Large ( $\geq 25,000$ people) & $\begin{array}{c}14,249 \\
(60.76 \%) \\
\end{array}$ & $\begin{array}{c}853 \\
(5.99 \%) \\
\end{array}$ & $\begin{array}{c}13,396 \\
(94.01 \%) \\
\end{array}$ & $\begin{array}{c}0.99 \\
(0.89-1.11) \\
\end{array}$ \\
\hline \multicolumn{5}{|l|}{ Service Type } \\
\hline Fire-Based & $\begin{array}{c}8,544 \\
(36.43 \%) \\
\end{array}$ & $\begin{array}{c}359 \\
(4.20 \%) \\
\end{array}$ & $\begin{array}{c}8,185 \\
(95.80 \%) \\
\end{array}$ & Referent \\
\hline County or Municipal & $\begin{array}{c}3,107 \\
(13.25 \%) \\
\end{array}$ & $\begin{array}{c}265 \\
(8.53 \%) \\
\end{array}$ & $\begin{array}{c}2,842 \\
(91.47 \%) \\
\end{array}$ & $\begin{array}{c}2.12 \\
(1.80-2.50) \\
\end{array}$ \\
\hline Private & $\begin{array}{c}4,873 \\
(20.78 \%) \\
\end{array}$ & $\begin{array}{c}421 \\
(8.64 \%) \\
\end{array}$ & $\begin{array}{c}4,452 \\
(91.36 \%) \\
\end{array}$ & $\begin{array}{c}2.16 \\
(1.86-2.49) \\
\end{array}$ \\
\hline Hospital-Based & $\begin{array}{c}2,470 \\
(10.53 \%) \\
\end{array}$ & $\begin{array}{c}189 \\
(7.65 \%) \\
\end{array}$ & $\begin{array}{c}2,281 \\
(92.35 \%) \\
\end{array}$ & $\begin{array}{c}1.89 \\
(1.57-2.27) \\
\end{array}$ \\
\hline Other & $\begin{array}{c}4,457 \\
(19.01 \%) \\
\end{array}$ & $\begin{array}{c}172 \\
(3.86 \%) \\
\end{array}$ & $\begin{array}{c}4,285 \\
(96.14 \%) \\
\end{array}$ & $\begin{array}{c}0.91 \\
(0.76-1.10) \\
\end{array}$ \\
\hline
\end{tabular}

Continued

Table 5. Anxiety Summary Statistics for Categorical Variables 
Table 5 Continued

\begin{tabular}{|c|c|c|c|c|}
\hline \multicolumn{5}{|l|}{ Experience } \\
\hline$\leq 2$ Years & $\begin{array}{c}3,410 \\
(14.54 \%)\end{array}$ & $\begin{array}{c}191 \\
(5.60 \%)\end{array}$ & $\begin{array}{c}3,219 \\
(94.40 \%)\end{array}$ & Referent \\
\hline 3-7 Years & $\begin{array}{c}7,445 \\
(31.75 \%) \\
\end{array}$ & $\begin{array}{c}419 \\
(5.63 \%) \\
\end{array}$ & $\begin{array}{c}7,026 \\
(94.37 \%) \\
\end{array}$ & $\begin{array}{c}1.00 \\
(0.84-1.20) \\
\end{array}$ \\
\hline 8-15 Years & $\begin{array}{c}7,269 \\
(31.00 \%) \\
\end{array}$ & $\begin{array}{c}468 \\
(6.44 \%) \\
\end{array}$ & $\begin{array}{c}6,801 \\
(93.56 \%) \\
\end{array}$ & $\begin{array}{c}1.16 \\
(0.98-1.38) \\
\end{array}$ \\
\hline$\geq 16$ Years & $\begin{array}{c}5,327 \\
(22.72 \%) \\
\end{array}$ & $\begin{array}{c}328 \\
(6.16 \%) \\
\end{array}$ & $\begin{array}{c}4,999 \\
(93.84 \%) \\
\end{array}$ & $\begin{array}{c}1.10 \\
(0.92-1.32) \\
\end{array}$ \\
\hline \multicolumn{5}{|l|}{ Call Volume } \\
\hline Low (0-9 calls) & $\begin{array}{c}11,747 \\
(50.09 \%) \\
\end{array}$ & $\begin{array}{c}610 \\
(5.19 \%) \\
\end{array}$ & $\begin{array}{c}11,137 \\
(94.81 \%) \\
\end{array}$ & Referent \\
\hline Moderate (10-39 calls) & $\begin{array}{c}10,333 \\
(44.06 \%) \\
\end{array}$ & $684(6.62 \%)$ & $\begin{array}{c}9,649 \\
(93.38 \%) \\
\end{array}$ & $\begin{array}{c}1.29 \\
(1.15-1.44) \\
\end{array}$ \\
\hline High $(40+$ calls $)$ & $\begin{array}{c}1,371 \\
(5.85 \%) \\
\end{array}$ & $\begin{array}{c}112 \\
(8.17 \%) \\
\end{array}$ & $\begin{array}{c}1,259 \\
(91.83 \%) \\
\end{array}$ & $\begin{array}{c}1.62 \\
(1.32-2.00) \\
\end{array}$ \\
\hline \multicolumn{5}{|l|}{ Race } \\
\hline Non-Minority & $\begin{array}{c}19,930 \\
(84.99 \%) \\
\end{array}$ & $\begin{array}{c}1,220 \\
(6.12 \%) \\
\end{array}$ & $\begin{array}{c}18,710 \\
(93.88 \%) \\
\end{array}$ & Referent \\
\hline Minority & $\begin{array}{c}3,521 \\
(15.01 \%) \\
\end{array}$ & $\begin{array}{c}186 \\
(5.28 \%) \\
\end{array}$ & $\begin{array}{c}3,335 \\
(94.72 \%) \\
\end{array}$ & $\begin{array}{c}0.85 \\
(0.73-1.00) \\
\end{array}$ \\
\hline \multicolumn{5}{|l|}{ Education } \\
\hline $\begin{array}{l}\text { Less than a College } \\
\text { Degree }\end{array}$ & $\begin{array}{c}12,964 \\
(55.28 \%) \\
\end{array}$ & $\begin{array}{c}801 \\
(6.18 \%) \\
\end{array}$ & $\begin{array}{c}12,163 \\
(93.82 \%) \\
\end{array}$ & Referent \\
\hline $\begin{array}{l}\text { College Degree or } \\
\text { Higher }\end{array}$ & $\begin{array}{c}10,487 \\
(44.72 \%) \\
\end{array}$ & $\begin{array}{c}605 \\
(5.77 \%) \\
\end{array}$ & $\begin{array}{c}9,882 \\
(94.23 \%) \\
\end{array}$ & $\begin{array}{c}0.93 \\
(0.83-1.03) \\
\end{array}$ \\
\hline \multicolumn{5}{|l|}{ Gender } \\
\hline Male & $\begin{array}{c}17,326 \\
(73.88 \%) \\
\end{array}$ & $\begin{array}{c}977 \\
(5.64 \%) \\
\end{array}$ & $\begin{array}{c}16,349 \\
(94.36 \%) \\
\end{array}$ & Referent \\
\hline Female & $\begin{array}{c}6,125 \\
(26.12 \%) \\
\end{array}$ & $\begin{array}{c}429 \\
(7.00 \%) \\
\end{array}$ & $\begin{array}{c}5,696 \\
(93.00 \%) \\
\end{array}$ & $\begin{array}{c}1.26 \\
(1.12-1.42) \\
\end{array}$ \\
\hline \multicolumn{5}{|l|}{ Marital Status } \\
\hline Married & $\begin{array}{c}14,730 \\
(62.81 \%) \\
\end{array}$ & $\begin{array}{c}798 \\
(5.42 \%) \\
\end{array}$ & $\begin{array}{c}13,932 \\
(94.58 \%) \\
\end{array}$ & Referent \\
\hline $\begin{array}{l}\text { Divorced/Widowed/ } \\
\text { Separated }\end{array}$ & $\begin{array}{c}3,132 \\
(13.36 \%) \\
\end{array}$ & $\begin{array}{c}231 \\
(7.38 \%) \\
\end{array}$ & $\begin{array}{c}2,901 \\
(92.62 \%) \\
\end{array}$ & $\begin{array}{c}1.39 \\
(1.19-1.62) \\
\end{array}$ \\
\hline Never Been Married & $\begin{array}{c}5,589 \\
(23.83 \%) \\
\end{array}$ & $\begin{array}{c}377 \\
(6.75 \%) \\
\end{array}$ & $\begin{array}{c}5,212 \\
(93.25 \%) \\
\end{array}$ & $\begin{array}{c}1.26 \\
(1.11-1.43) \\
\end{array}$ \\
\hline
\end{tabular}

Continued 
Table 5 Continued

\begin{tabular}{|c|c|c|c|c|}
\hline \multicolumn{5}{|l|}{ General Health } \\
\hline Excellent & $\begin{array}{c}6,185 \\
(26.37 \%)\end{array}$ & $\begin{array}{c}153 \\
(2.47 \%)\end{array}$ & $\begin{array}{c}6,032 \\
(97.53 \%)\end{array}$ & Referent \\
\hline Very Good & $\begin{array}{c}10,653 \\
(45.43 \%) \\
\end{array}$ & $\begin{array}{c}502 \\
(4.71 \%) \\
\end{array}$ & $\begin{array}{c}10,151 \\
(95.29 \%) \\
\end{array}$ & $\begin{array}{c}1.95 \\
(1.62-2.34) \\
\end{array}$ \\
\hline Good & $\begin{array}{c}6,207 \\
(26.47 \%) \\
\end{array}$ & $\begin{array}{c}641 \\
(10.33 \%) \\
\end{array}$ & $\begin{array}{c}5,566 \\
(86.97 \%) \\
\end{array}$ & $\begin{array}{c}5.54 \\
(3.79-5.43)\end{array}$ \\
\hline Fair/Poor & $\begin{array}{c}406 \\
(1.73 \%) \\
\end{array}$ & $\begin{array}{c}110 \\
(27.09 \%) \\
\end{array}$ & $\begin{array}{c}296 \\
(72.91 \%) \\
\end{array}$ & $\begin{array}{c}16.65 \\
(11.17-19.21) \\
\end{array}$ \\
\hline \multicolumn{5}{|c|}{ Exercise in the Past Month } \\
\hline Yes & $\begin{array}{c}20,930 \\
(89.25 \%) \\
\end{array}$ & $\begin{array}{c}1,099 \\
(5.25 \%) \\
\end{array}$ & $\begin{array}{c}19,831 \\
(94.75 \%) \\
\end{array}$ & Referent \\
\hline No & $\begin{array}{c}2,521 \\
(10.75 \%) \\
\end{array}$ & $\begin{array}{c}307 \\
(12.18 \%) \\
\end{array}$ & $\begin{array}{c}2,214 \\
(87.82 \%) \\
\end{array}$ & $\begin{array}{c}2.50 \\
(2.19-2.86) \\
\end{array}$ \\
\hline \multicolumn{5}{|l|}{ Smoking Status } \\
\hline Never Smoker & $\begin{array}{c}3,473 \\
(14.81 \%) \\
\end{array}$ & $\begin{array}{c}296 \\
(8.52 \%) \\
\end{array}$ & $\begin{array}{c}3,177 \\
(91.48 \%) \\
\end{array}$ & Referent \\
\hline Former/Ever Smoker & $\begin{array}{c}4,877 \\
(20.80 \%)\end{array}$ & $\begin{array}{c}345 \\
(7.07 \%) \\
\end{array}$ & $\begin{array}{c}4,532 \\
(92.93 \%) \\
\end{array}$ & $\begin{array}{c}1.43 \\
(1.25-1.63) \\
\end{array}$ \\
\hline Current Smoker & $\begin{array}{c}15,101 \\
(64.39 \%) \\
\end{array}$ & $\begin{array}{c}765 \\
(5.07 \%) \\
\end{array}$ & $\begin{array}{c}14,336 \\
(94.93 \%) \\
\end{array}$ & $\begin{array}{c}1.74 \\
(1.52-2.01) \\
\end{array}$ \\
\hline
\end{tabular}

\begin{tabular}{|c|c|c|c|}
\hline & n (\%) & Mean (SD) & $\begin{array}{c}\text { Univariable OR } \\
(95 \% \mathrm{CI})\end{array}$ \\
\hline \multicolumn{4}{|l|}{ Age } \\
\hline Anxious & $1,406(6.00 \%)$ & 37.18 years $(10.05)$ & \multirow{3}{*}{$\begin{array}{c}0.99 \\
(0.98-1.00)\end{array}$} \\
\hline Non-Anxious & $22,045(94.00 \%)$ & 37.82 years $(10.27)$ & \\
\hline Total Population & & 37.78 years $(10.27)$ & \\
\hline \multicolumn{4}{|l|}{ BMI } \\
\hline Anxious & $1,406(6.00 \%)$ & 29.49 lbs/inches ${ }^{2}(6.44)$ & \multirow{3}{*}{$\begin{array}{c}1.04 \\
(1.03-1.05)\end{array}$} \\
\hline Non-Anxious & $22,045(94.00 \%)$ & $28.05 \mathrm{lbs} /$ inches $^{2}(5.13)$ & \\
\hline Total Population & & 28.14 lbs/inches ${ }^{2}(5.23)$ & \\
\hline
\end{tabular}

Table 6. Anxiety Summary Statistics for Continuous Variables 
There were 11 independent variables statistically significant in the univariate anxiety analysis. The odds of anxiety among Paramedics was 1.24 (95\% CI=1.18-1.31) times the odds of anxiety among EMT-Basics. With regards to EMS service type, when compared to EMS professionals working in a fire-based setting, those working in a county or municipal service were $2.12(95 \% \mathrm{CI}=1.80-2.50)$ as likely, those working in a private service were $2.16(95 \% \mathrm{CI}=1.86-2.49)$ times as likely, those in a hospital-based service were $1.89(95 \% \mathrm{CI}=1.57-2.27)$ times as likely, and those in other service types were $0.91(95 \% \mathrm{CI}=0.76-1.10)$ times as likely to be anxious. A small step-wise increase was found with regards to call volume. The odds of anxiety among those working a moderate call volume were $1.29(95 \% \mathrm{CI}=1.15-1.44)$ times the odds of anxiety among those working a low call volume. Likewise, the odds of anxiety among those working a high call volume were $1.62(95 \% \mathrm{CI}=1.32-2.00)$ times the odds of anxiety among those working a low call volume. Race was marginally significant with minority status showing possible protective effects on anxiety $(\mathrm{OR}=0.85,95 \% \mathrm{CI}=0.73-1.00)$. The odds of anxiety among female EMS professionals was $1.26(95 \% \mathrm{CI}=1.12-1.42)$ times the odds of anxiety among male EMS professionals. With respect to marital status, those who were divorced/widowed/separated were $1.39(95 \% \mathrm{CI}=1.19-1.62)$ times as likely and those who had never been married were $1.26(95 \% \mathrm{CI}=1.11-1.43)$ times as likely to be anxious. Another monotonic increase was observed when comparing self-reported general health. With those in excellent health being referent, those in very good health were $1.95(95 \% \mathrm{CI}=1.62-2.34)$ times as likely, those in good health were $5.54(95 \%$ $\mathrm{CI}=3.79-5.43)$ times as likely, and those in fair/poor health were $16.65(95 \% \mathrm{CI}=11.17$ - 
19.21) times as likely to be anxious. The odds of anxiety among those EMS

professionals who did not exercise in the past month was $2.50(95 \% \mathrm{CI}=2.19-2.86)$ times

the odds of those EMS professionals that did exercise. With respect to smoking status, those who reported being former/ever smokers were $1.43(95 \% \mathrm{CI}=1.25-1.63)$ times as

likely, and those who reported being current smokers were $1.74(95 \% \mathrm{CI}=1.52-2.01)$

times as likely to be anxious. Age and BMI were also found to be significant with respect to anxiety $(\mathrm{OR}=0.99,95 \% \mathrm{CI}=0.98-1.00$ and $\mathrm{OR}=1.04,95 \% \mathrm{CI}=1.03-1.05$, respectively).

\subsubsection{Stress}

Table 7 presents descriptive statistics for all categorical variables. Table 8 presents descriptive statistics for all continuous variables.

\begin{tabular}{|c|c|c|c|c|}
\hline & $\begin{array}{c}\text { Total } \\
\text { Sample }\end{array}$ & Stressed & $\begin{array}{c}\text { Non- } \\
\text { Stressed }\end{array}$ & $\begin{array}{c}\text { Univariable OR } \\
(95 \% \mathrm{CI})\end{array}$ \\
\hline & $\mathrm{n}(\%)$ & $\mathrm{n}(\%)$ & $\mathrm{n}(\%)$ & \\
\hline \multicolumn{5}{|l|}{ Certification Level } \\
\hline EMT-Basic & $\begin{array}{c}12,212 \\
(52.07 \%)\end{array}$ & $\begin{array}{c}460 \\
(3.77 \%)\end{array}$ & $\begin{array}{c}11,752 \\
(96.23 \%)\end{array}$ & Referent \\
\hline Paramedic & $\begin{array}{c}11,239 \\
(47.93 \%) \\
\end{array}$ & $\begin{array}{c}922 \\
(8.20 \%) \\
\end{array}$ & $\begin{array}{c}10,317 \\
(91.80 \%) \\
\end{array}$ & $\begin{array}{c}1.51 \\
(1.42-1.60) \\
\end{array}$ \\
\hline \multicolumn{5}{|l|}{ Community Size } \\
\hline Small $(<25,000$ people $)$ & $\begin{array}{c}9,202 \\
(39.24 \%)\end{array}$ & $\begin{array}{c}498 \\
(5.41 \%)\end{array}$ & $\begin{array}{c}8,704 \\
(94.59 \%)\end{array}$ & Referent \\
\hline Large ( $\geq 25,000$ people) & $\begin{array}{c}14,249 \\
(60.76 \%) \\
\end{array}$ & $\begin{array}{c}884 \\
(6.20 \%) \\
\end{array}$ & $\begin{array}{c}13,365 \\
(93.80 \%) \\
\end{array}$ & $\begin{array}{c}1.16 \\
(1.03-1.29) \\
\end{array}$ \\
\hline
\end{tabular}

Continued

Table 7. Stress Summary Statistics for Categorical Variables 
Table 7 Continued

\begin{tabular}{|c|c|c|c|c|}
\hline \multicolumn{5}{|l|}{ Service Type } \\
\hline Fire-Based & $\begin{array}{c}8,544 \\
(36.43 \%)\end{array}$ & $\begin{array}{c}411 \\
(4.81 \%)\end{array}$ & $\begin{array}{c}8,133 \\
(95.19 \%)\end{array}$ & Referent \\
\hline County or Municipal & $\begin{array}{c}3,107 \\
(13.25 \%) \\
\end{array}$ & $\begin{array}{c}230 \\
(7.40 \%) \\
\end{array}$ & $\begin{array}{c}2,877 \\
(92.60 \%) \\
\end{array}$ & $\begin{array}{c}1.58 \\
(1.34-1.87) \\
\end{array}$ \\
\hline Private & $\begin{array}{c}4,873 \\
(20.78 \%)\end{array}$ & $\begin{array}{c}388 \\
(7.96 \%)\end{array}$ & $\begin{array}{c}4,485 \\
(92.04 \%)\end{array}$ & $\begin{array}{c}1.71 \\
(1.48-1.97)\end{array}$ \\
\hline Hospital-Based & $\begin{array}{c}2,470 \\
(10.53 \%) \\
\end{array}$ & $\begin{array}{c}180 \\
(7.29 \%) \\
\end{array}$ & $\begin{array}{c}2,290 \\
(92.71 \%) \\
\end{array}$ & $\begin{array}{c}1.55 \\
(1.30-1.86) \\
\end{array}$ \\
\hline Other & $\begin{array}{c}4,457 \\
(19.01 \%) \\
\end{array}$ & $\begin{array}{c}173 \\
(3.88 \%) \\
\end{array}$ & $\begin{array}{c}4,284 \\
(96.12 \%) \\
\end{array}$ & $\begin{array}{c}0.80 \\
(0.66-0.96) \\
\end{array}$ \\
\hline \multicolumn{5}{|l|}{ Experience } \\
\hline$\leq 2$ Years & $\begin{array}{c}3,410 \\
(14.54 \%) \\
\end{array}$ & $\begin{array}{c}128 \\
(3.75 \%) \\
\end{array}$ & $\begin{array}{c}3,282 \\
(96.25 \%) \\
\end{array}$ & Referent \\
\hline 3-7 Years & $\begin{array}{c}7,445 \\
(31.75 \%) \\
\end{array}$ & $\begin{array}{c}365 \\
(4.90 \%) \\
\end{array}$ & $\begin{array}{c}7,080 \\
(95.10 \%) \\
\end{array}$ & $\begin{array}{c}1.32 \\
(1.08-1.62) \\
\end{array}$ \\
\hline $8-15$ Years & $\begin{array}{c}7,269 \\
(31.00 \%) \\
\end{array}$ & $\begin{array}{c}524 \\
(7.21 \%) \\
\end{array}$ & $\begin{array}{c}6,745 \\
(92.79 \%) \\
\end{array}$ & $\begin{array}{c}1.99 \\
(1.63-2.43) \\
\end{array}$ \\
\hline$\geq 16$ Years & $\begin{array}{c}5,327 \\
(22.72 \%) \\
\end{array}$ & $\begin{array}{c}365 \\
(6.85 \%) \\
\end{array}$ & $\begin{array}{c}4,962 \\
(93.15 \%) \\
\end{array}$ & $\begin{array}{c}1.89 \\
(1.53-2.32) \\
\end{array}$ \\
\hline \multicolumn{5}{|l|}{ Call Volume } \\
\hline Low (0-9 calls) & $\begin{array}{c}11,747 \\
(50.09 \%) \\
\end{array}$ & $\begin{array}{c}554 \\
(4.72 \%) \\
\end{array}$ & $\begin{array}{c}11,193 \\
(95.28 \%) \\
\end{array}$ & Referent \\
\hline Moderate (10-39 calls) & $\begin{array}{c}10,333 \\
(44.06 \%) \\
\end{array}$ & $\begin{array}{c}723 \\
(7.00 \%) \\
\end{array}$ & $\begin{array}{c}9,610 \\
(93.00 \%) \\
\end{array}$ & $\begin{array}{c}1.52 \\
(1.36-1.70) \\
\end{array}$ \\
\hline High $(40+$ calls $)$ & $\begin{array}{c}1,371 \\
(5.85 \%) \\
\end{array}$ & $\begin{array}{c}105 \\
(7.66 \%) \\
\end{array}$ & $\begin{array}{c}1,266 \\
(92.34 \%) \\
\end{array}$ & $\begin{array}{c}1.68 \\
(1.35-2.08) \\
\end{array}$ \\
\hline \multicolumn{5}{|l|}{ Race } \\
\hline Non-Minority & $\begin{array}{c}19,930 \\
(84.99 \%) \\
\end{array}$ & $\begin{array}{c}1,242 \\
(6.23 \%) \\
\end{array}$ & $\begin{array}{c}18,688 \\
(93.77 \%) \\
\end{array}$ & Referent \\
\hline Minority & $\begin{array}{c}3,521 \\
(15.01 \%) \\
\end{array}$ & $\begin{array}{c}140 \\
(3.98 \%) \\
\end{array}$ & $\begin{array}{c}3,381 \\
(96.02 \%) \\
\end{array}$ & $\begin{array}{c}0.62 \\
(0.52-0.74) \\
\end{array}$ \\
\hline \multicolumn{5}{|l|}{ Education } \\
\hline $\begin{array}{l}\text { Less than a College } \\
\text { Degree }\end{array}$ & $\begin{array}{c}12,964 \\
(55.28 \%) \\
\end{array}$ & $\begin{array}{c}730 \\
(5.63 \%) \\
\end{array}$ & $\begin{array}{c}12,234 \\
(94.37 \%) \\
\end{array}$ & Referent \\
\hline $\begin{array}{l}\text { College Degree or } \\
\text { Higher }\end{array}$ & $\begin{array}{c}10,487 \\
(44.72 \%) \\
\end{array}$ & $\begin{array}{c}652 \\
(6.22 \%) \\
\end{array}$ & $\begin{array}{c}9,835 \\
(93.78 \%) \\
\end{array}$ & $\begin{array}{c}1.11 \\
(1.00-1.24) \\
\end{array}$ \\
\hline \multicolumn{5}{|l|}{ Gender } \\
\hline Male & $\begin{array}{c}17,326 \\
(73.88 \%) \\
\end{array}$ & $\begin{array}{c}1,011 \\
(5.84 \%) \\
\end{array}$ & $\begin{array}{c}16,315 \\
(94.16 \%) \\
\end{array}$ & Referent \\
\hline Female & $\begin{array}{c}6,125 \\
(26.12 \%) \\
\end{array}$ & $\begin{array}{c}371 \\
(6.06 \%) \\
\end{array}$ & $\begin{array}{c}5,754 \\
(93.94 \%) \\
\end{array}$ & $\begin{array}{c}1.04 \\
(0.92-1.18) \\
\end{array}$ \\
\hline
\end{tabular}

Continued 
Table 7 Continued

\begin{tabular}{|c|c|c|c|c|}
\hline \multicolumn{5}{|l|}{ Marital Status } \\
\hline Married & $\begin{array}{c}14,730 \\
(62.81 \%)\end{array}$ & $\begin{array}{c}862 \\
(5.85 \%)\end{array}$ & $\begin{array}{c}13,868 \\
(94.15 \%)\end{array}$ & Referent \\
\hline $\begin{array}{l}\text { Divorced/Widowed/ } \\
\text { Separated }\end{array}$ & $\begin{array}{c}3,132 \\
(13.36 \%) \\
\end{array}$ & $\begin{array}{c}201 \\
(6.42 \%) \\
\end{array}$ & $\begin{array}{c}2,931 \\
(93.58 \%) \\
\end{array}$ & $\begin{array}{c}1.10 \\
(0.94-1.29) \\
\end{array}$ \\
\hline Never Been Married & $\begin{array}{c}5,589 \\
(23.83 \%) \\
\end{array}$ & $\begin{array}{c}319 \\
(5.71 \%) \\
\end{array}$ & $\begin{array}{c}5,270 \\
(94.29 \%) \\
\end{array}$ & $\begin{array}{c}0.97 \\
(0.85-1.11) \\
\end{array}$ \\
\hline \multicolumn{5}{|l|}{ General Health } \\
\hline Excellent & $\begin{array}{c}6,185 \\
(26.37 \%) \\
\end{array}$ & $\begin{array}{c}183 \\
(13.24 \%) \\
\end{array}$ & $\begin{array}{c}6,002 \\
(27.20 \%) \\
\end{array}$ & Referent \\
\hline Very Good & $\begin{array}{c}10,653 \\
(45.43 \%) \\
\end{array}$ & $\begin{array}{c}539 \\
(39.00 \%) \\
\end{array}$ & $\begin{array}{c}10,114 \\
(45.83 \%) \\
\end{array}$ & $\begin{array}{c}1.74 \\
(1.47-2.01) \\
\end{array}$ \\
\hline Good & $\begin{array}{c}6,207 \\
(26.47 \%) \\
\end{array}$ & $\begin{array}{c}574 \\
(41.53 \%) \\
\end{array}$ & $\begin{array}{c}5,633 \\
(25.52 \%) \\
\end{array}$ & $\begin{array}{c}3.34 \\
(2.81-3.96) \\
\end{array}$ \\
\hline Fair/Poor & $\begin{array}{c}406 \\
(1.73 \%) \\
\end{array}$ & $\begin{array}{c}86 \\
(6.22 \%) \\
\end{array}$ & $\begin{array}{c}320 \\
(1.45 \%) \\
\end{array}$ & $\begin{array}{c}8.81 \\
(6.66-11.66) \\
\end{array}$ \\
\hline \multicolumn{5}{|c|}{ Exercise in the Past Month } \\
\hline Yes & $\begin{array}{c}20,930 \\
(89.25 \%)\end{array}$ & $\begin{array}{c}1,077 \\
(5.15 \%)\end{array}$ & $\begin{array}{c}19,853 \\
(94.85 \%) \\
\end{array}$ & Referent \\
\hline No & $\begin{array}{c}2,521 \\
(10.75 \%) \\
\end{array}$ & $\begin{array}{c}305 \\
(12.10 \%) \\
\end{array}$ & $\begin{array}{c}2,216 \\
(87.90 \%) \\
\end{array}$ & $\begin{array}{c}2.53 \\
(2.22-2.90) \\
\end{array}$ \\
\hline \multicolumn{5}{|l|}{ Smoking Status } \\
\hline Never Smoker & $\begin{array}{c}3,473 \\
(14.81 \%) \\
\end{array}$ & $\begin{array}{c}278 \\
(8.00 \%) \\
\end{array}$ & $\begin{array}{c}3,195 \\
(92.00 \%) \\
\end{array}$ & Referent \\
\hline Former/Ever Smoker & $\begin{array}{c}4,877 \\
(20.80 \%) \\
\end{array}$ & $\begin{array}{c}335 \\
(6.87 \%) \\
\end{array}$ & $\begin{array}{c}4,542 \\
(93.13 \%) \\
\end{array}$ & $\begin{array}{c}1.37 \\
(1.20-1.57) \\
\end{array}$ \\
\hline Current Smoker & $\begin{array}{c}15,101 \\
(64.39 \%) \\
\end{array}$ & $\begin{array}{c}769 \\
(5.09 \%) \\
\end{array}$ & $\begin{array}{c}14,332 \\
(94.91 \%) \\
\end{array}$ & $\begin{array}{c}1.62 \\
(1.41-1.87) \\
\end{array}$ \\
\hline
\end{tabular}




\begin{tabular}{|c|c|c|c|}
\hline & n (\%) & Mean (SD) & $\begin{array}{c}\text { Univariable } \\
\text { OR }(95 \% \text { CI })\end{array}$ \\
\hline \multicolumn{4}{|l|}{ Age } \\
\hline Stressed & $1,382(5.89 \%)$ & 37.06 years $(8.80)$ & \multirow{3}{*}{$0.99(0.99-0.99)$} \\
\hline Non-Stressed & $22,069(94.11 \%)$ & 37.83 years $(10.34)$ & \\
\hline Total Population & & 37.78 years $(10.27)$ & \\
\hline \multicolumn{4}{|l|}{$B M I$} \\
\hline Stressed & $1,382(5.89 \%)$ & $29.38 \mathrm{lbs} /$ inches $^{2}(6.23)$ & \multirow{3}{*}{$1.04(1.03-1.05)$} \\
\hline Non-Stressed & $22,069(94.11 \%)$ & $28.06 \mathrm{lbs} /$ inches $^{2}(5.15)$ & \\
\hline Total Population & & $28.14 \mathrm{lbs} /$ inches $^{2}(5.23)$ & \\
\hline
\end{tabular}

Table 8. Stress Descriptive Statistics for Continuous Variables

There were 11 independent variables statistically significant with respect to stress. The odds of stress among Paramedics was 1.51 (95\% CI=1.42-1.60) times the odds of stress among EMT-Basics. Further, the odds of stress among those EMS professional working in a small community was $1.16(95 \% \mathrm{CI}=1.03-1.29)$ times the odds of stress among those working in a large community. With respect to EMS service type, when compared to EMS professionals working in a fire-based service, those working in a county or municipal service were $1.58(95 \% \mathrm{CI}=1.34-1.87)$ times as likely, those working in a private service were $1.71(95 \% \mathrm{CI}=1.48-1.97)$ times as likely, those working in a hospital-based service were $1.55(95 \% \mathrm{CI}=1.30-1.86)$ times as likely, and those in other services were $0.80(95 \% \mathrm{CI}=0.66-0.96)$ times as likely to be stressed. With respect to EMS years of experience, using EMS professionals with two or less years of experience as the referent, those with 3-7 years were $1.32(95 \% \mathrm{CI}=1.08-1.62)$ times as likely, those with 8-15 years of experience were $1.99(95 \% \mathrm{CI}=1.63-2.43)$ more likely, and those with $\geq 16$ years of experience were $1.89(95 \% \mathrm{CI}=1.53-2.32)$ times more likely to be stressed. 
The odds of being stressed among those EMS professionals with a moderate call volume were $1.52(95 \% \mathrm{CI}=1.36-1.70)$ times the odds of being stressed among those with a low call volume. Further, the odds of being stressed among those EMS professionals with a high call volume were $1.68(95 \% \mathrm{CI}=1.35-2.08)$ times the odds of being stressed among those with a low call volume. With respect to race, the odds of being stressed among minorities were $0.62(95 \% \mathrm{CI}=0.52-0.74)$ times the odds of being stressed among nonminorities. With those in excellent health being referent, those in very good health were $1.74(95 \% \mathrm{CI}=1.47-2.01)$ times as likely, those in good health were $3.34(95 \% \mathrm{CI}=2.81-$ 3.96) times as likely, and those in fair/poor health were $8.84(95 \% \mathrm{CI}=6.66-11.66)$ times as likely to be anxious. The odds of being stressed among those EMS professionals who self-reported not exercising in the past month were $2.53(95 \% \mathrm{CI}=2.22-2.90)$ times the odds of being stressed among those who did exercise. A step-wise increase was found with respect to smoking status. With never smokers being referent, former/ever smokers were $1.37(95 \% \mathrm{CI}=1.20-1.57)$ times as likely and current smokers were $1.62(95 \%$ $\mathrm{CI}=1.41-1.87)$ times as likely to be stressed. Lastly, age ( $\mathrm{OR}=0.99,95 \% \mathrm{CI}==0.99-0.99)$ and $\mathrm{BMI}(\mathrm{OR}=1.04,95 \% \mathrm{CI}=1.03-1.05)$ were found to statistically significant with respect to stress. 


\subsection{Multivariable Analysis}

\subsubsection{Assessment of Confounding}

Detailed backwards assessment of confounding was conducted for each model and is given in Appendix C. For each of the three models each possible independent variable confounder did not possess a significant percentage $(\geq 10-15 \%)$ difference between the adjusted and unadjusted odds ratio and were not included as confounders.

\subsubsection{Assessment of Possible Interactions}

Stratified tables to identify possible interactions may be found in Appendix D. A priori hypothesized possible interactions included BMI and general health, general health and smoking, general health and exercise, race and education, race and community size, and certification level and years of experience. Stratum-specific odds ratios were calculated for each model and each interaction. Stratum-specific odds ratios were similar in each of the above interactions except for the interaction between general health and smoking. As such, the only interaction term assessed in each of the three models was between general health and smoking.

The interaction of general health and smoking was tested in each of the outcome models. With regards to depression, the general health and smoking interaction was not found to be significant ( $\mathrm{p}$-value $=0.6826)$. With regards to the outcome of anxiety, the interaction of general health and smoking status was found to be not significant ( $\mathrm{p}$ value $=0.7002$ ). Lastly, with respect to stress, the potential interaction between self- 
reported general health status and smoking status was found to be non-significant (pvalue $=0.9244)$. The interaction between self-reported general health and smoking status was found not to be significant was not included in the final models.

\subsubsection{Final Logistic Regression Models}

\subsubsection{Depression}

The final logistic regression model for depression is presented in Table 9.

\begin{tabular}{|c|c|c|}
\hline Variable Name & $\overline{\text { OR }}$ & $95 \%$ CI \\
\hline \multicolumn{3}{|l|}{ Certification Level } \\
\hline EMT-Basic & Referent & - \\
\hline Paramedic & 1.31 & $1.22-1.39$ \\
\hline \multicolumn{3}{|l|}{ Service Type } \\
\hline Fire-Based & Referent & - \\
\hline County or Municipal & 1.36 & $1.16-1.60$ \\
\hline Private & 1.32 & $1.14-1.52$ \\
\hline Hospital-Based & 1.35 & $1.13-1.61$ \\
\hline Other & 1.02 & $0.85-1.23$ \\
\hline \multicolumn{3}{|l|}{ Experience } \\
\hline$\leq 2$ Years & Referent & - \\
\hline 3-7 Years & 0.83 & $0.68-1.01$ \\
\hline 8-15 Years & 1.13 & $0.92-1.39$ \\
\hline$\geq 16$ Years & 1.28 & $1.01-1.62$ \\
\hline \multicolumn{3}{|l|}{ Gender } \\
\hline Male & Referent & - \\
\hline Female & 0.84 & $0.74-0.95$ \\
\hline \multicolumn{3}{|l|}{ Race } \\
\hline Non-minority & Referent & - \\
\hline Minority & 0.82 & $0.69-0.97$ \\
\hline
\end{tabular}

Continued

Table 9. Depression: Final Logistic Regression Model 
Table 9 continued

\begin{tabular}{|l|c|c|}
\hline \multicolumn{3}{|l|}{ Education Level } \\
\hline Less than College Degree & Referent & -- \\
\hline College Degree & 1.15 & $1.02-1.28$ \\
\hline Marital Status & Referent & -- \\
\hline Married & 1.56 & $1.35-1.81$ \\
\hline Divorced/Widowed/Separated & 1.54 & $1.34-1.76$ \\
\hline Never Been Married & Referent & -- \\
\hline General Health & 2.01 & $1.69-2.40$ \\
\hline Excellent & 3.59 & $3.01-4.30$ \\
\hline Very Good & 9.97 & $7.57-13.14$ \\
\hline Good & Referent & -- \\
\hline Fair/Poor & 1.81 & $1.58-2.07$ \\
\hline Exercise Status & Referent & -- \\
\hline Yes & 1.16 & $1.02-1.32$ \\
\hline No/Don't Know & 1.24 & $1.07-1.43$ \\
\hline Smoking Status & 0.99 & $0.98-1.00$ \\
\hline Never Smoker & Former/Ever Smoker \\
\hline Current Smoker & Age & \\
\hline
\end{tabular}

After adjustment for other variables in the model, the odds of depression among Paramedics were $1.31(95 \% \mathrm{CI}=1.22-1.39)$ times the odds of depression among EMTBasics. With respect to service type, county or municipal services $(\mathrm{OR}=1.36,95 \%$ $\mathrm{CI}=1.16-1.60)$, private services $(\mathrm{OR}=1.32,95 \% \mathrm{CI}=1.14-1.52)$, hospital-based services $(\mathrm{OR}=1.35,95 \% \mathrm{CI}=1.13-1.61)$, and other types of services $(\mathrm{OR}=1.02,95 \% \mathrm{CI}=0.85$ 1.23) had a higher odds of depression than fire-based services. When compared to those EMS professionals who had two years of experience or less, those with 3-7 years of experience were $0.83(95 \% \mathrm{CI}=0.68-1.01)$ less likely, those with 8 -15 years of experience 
were $1.13(95 \% \mathrm{CI}=0.92-1.39)$ more likely, those with $\geq 16$ years of experience were 1.28 (95\% CI $=1.01-1.62)$ more likely to be depressed. The odds of depression among females were $0.84(95 \% \mathrm{CI}=0.74-0.95)$ times the odds of depression among males. Futher, the odds of depression among self-reporting minority status were $0.82(95 \% \mathrm{CI}=0.69-0.97)$ times the odds of depression among those who self-reported non-minority status. With respect to education, EMS professionals who had a college degree were $1.15(95 \%$ $\mathrm{CI}=1.02-1.28)$ more likely to be depressed than EMS professionals who had less than a college degree. With respect to marital status, when those EMS professionals who were married were referent, those who were divorced/widowed/separated were $1.56(95 \%$ $\mathrm{CI}=1.35-1.81)$ more likely, and those who have never been married were 1.54 (95\% $\mathrm{CI}=1.34-1.76)$ more likely to be depressed. An increasing trend in the odds ratios was observed in self-reported general health. When compared to "excellent" general health, "very good" (OR=2.01, 95\% CI=1.69-2.40), "good" (OR=2.59, 95\% CI=3.01-4.30), and "fair/poor" ( $\mathrm{OR}=9.97,95 \% \mathrm{CI}=7.57-13.14)$ were at higher odds of being depressed. The odds of depression among those who did not exercise in the past month was $1.81(95 \%$ $\mathrm{CI}=1.58-2.07)$ times the odds of depression among those who did exercise in the past month. With respect to self-reported smoking status, those who were former/ever smokers and those who were current smokers had a higher odds of being depressed than those who were never smokers $(\mathrm{OR}=1.16,95 \% \mathrm{CI}=1.02-1.32$ and $\mathrm{OR}=1.24,95 \%$ $\mathrm{CI}=1.07-1.43$, respectively). Lastly, for every one year increase in age there was a corresponding 0.99 decrease in the odds of reporting being depressed $(95 \% \mathrm{CI}=0.98$ 1.00). All continuous variables were found to be linear in the logit. The Hosmer- 
Lemeshow goodness-of-fit test showed the depression model exhibited good fit $\left(\chi^{2}=6.31\right.$, $\mathrm{p}$-value $=0.6129)$.

\subsubsection{Anxiety}

The final logistic regression model for anxiety is presented in Table 10.

\begin{tabular}{|l|c|c|}
\hline Variable Name & OR & 95\% CI \\
\hline Certification Level & & \\
\hline EMT-Basic & Referent & -- \\
\hline Paramedic & 1.14 & $1.08-1.21$ \\
\hline Service Type & & \\
\hline Fire-Based & Referent & -- \\
\hline County or Municipal & 1.71 & $1.45-2.03$ \\
\hline Private & 1.64 & $1.41-1.91$ \\
\hline Hospital-Based & 1.51 & $1.25-1.82$ \\
\hline Other & 1.00 & $0.82-1.21$ \\
\hline Marital Status & & \\
\hline Married & Referent & -- \\
\hline Divorced/Widowed/Separated & 1.27 & $1.08-1.49$ \\
\hline Never Been Married & 1.25 & $1.09-1.44$ \\
\hline General Health & & \\
\hline Excellent & Referent & -- \\
\hline Very Good & 1.84 & $1.52-2.21$ \\
\hline Good & 3.88 & $3.23-4.67$ \\
\hline Fair/Poor & 10.81 & $8.14-14.34$ \\
\hline Exercise Status & & \\
\hline Yes & Referent & -- \\
\hline No/Don't Know & 1.56 & $1.35-1.80$ \\
\hline Smoking Status & Referent & \\
\hline Never Smoker & 1.34 & $1.17-1.53$ \\
\hline Former/Ever Smoker & 1.27 & $1.10-1.47$ \\
\hline Current Smoker & 0.98 & $0.98-0.99$ \\
\hline Age & & \\
\hline
\end{tabular}

Table 10. Anxiety: Final Logistic Regression Model 
After adjustment for all other variables in the model, the odds of anxiety among Paramedics was 1.14 (95\% CI=1.08-1.21) times the odds of anxiety among EMT-Basics. County or municipal, private, hospital-based EMS professionals were all more likely than fire-based professionals to be anxious (by $71 \%, 64 \%$, and $51 \%$, respectively). With respect to marital status, with married EMS professionals as referent, those EMS professionals were divorced/widowed/separated were $1.27(95 \% \mathrm{CI}=1.08-1.49)$ times as likely, and those who had never been married were 1.25 (95\% CI=1.09-1.44) times as likely to be anxious. An increasing trend in the odds ratios was observed in self-reported general health. When compared to those in excellent general health, those who reported very good $(\mathrm{OR}=1.84,95 \% \mathrm{CI}=1.52-2.21)$, $\operatorname{good}(\mathrm{OR}=3.88,95 \% \mathrm{CI}=3.23-4.67)$, and fair/poor health status $(\mathrm{OR}=10.81,95 \% \mathrm{CI}=8.14-14.34)$ were at a higher odds of being anxious. The odds of anxiety among those EMS professionals who self-reported no exercise in the past month was $1.56(95 \% \mathrm{CI}=1.35-1.80)$ times the odds of anxiety among those EMS professionals who did exercise. With respect to smoking status, former/ever smokers $(\mathrm{OR}=1.34,95 \% \mathrm{CI}=1.17-1.53)$ and current smokers $(\mathrm{OR}=1.27,95 \% \mathrm{CI}=1.10$ 1.47) were more likely to be anxious. Lastly, for every one year increase in the age of the EMS provider, the odds of being anxious decreased by 0.98 (95\% CI=0.98-0.99). All continuous variables were found to be linear in the logit. The Hosmer-Lemeshow goodness-of-fit test showed the anxiety model exhibited good fit $\left(\chi^{2}=14.27, \mathrm{p}-\right.$ value $=0.0749$ ). 


\subsubsection{Stress}

The final logistic regression model for stress is presented in Table 11.

\begin{tabular}{|c|c|c|}
\hline Variable Name & OR & $95 \% \mathrm{CI}$ \\
\hline \multicolumn{3}{|l|}{ Certification Level } \\
\hline EMT-Basic & Referent & -- \\
\hline Paramedic & 1.32 & $1.23-1.42$ \\
\hline \multicolumn{3}{|l|}{ Service Type } \\
\hline Fire-Based & Referent & $\overline{--}$ \\
\hline County or Municipal & 1.28 & $1.07-1.51$ \\
\hline Private & 1.35 & $1.16-1.56$ \\
\hline Hospital-Based & 1.19 & $0.99-1.43$ \\
\hline Other & 1.05 & $0.86-1.27$ \\
\hline \multicolumn{3}{|l|}{ Experience } \\
\hline$\leq 2$ Years & Referent & - \\
\hline 3-7 Years & 1.1 & $0.89-1.36$ \\
\hline $8-15$ Years & 1.56 & $1.24-1.95$ \\
\hline$\geq 16$ Years & 1.67 & $1.28-2.18$ \\
\hline \multicolumn{3}{|l|}{ Race } \\
\hline Non-minority & Referent & -- \\
\hline Minority & 0.76 & $0.63-0.91$ \\
\hline \multicolumn{3}{|l|}{ Education Level } \\
\hline $\begin{array}{l}\text { Less than College } \\
\text { Degree }\end{array}$ & Referent & -- \\
\hline College Degree & 1.22 & $1.09-1.37$ \\
\hline \multicolumn{3}{|l|}{ General Health } \\
\hline Excellent & Referent & -- \\
\hline Very Good & 1.6 & $1.35-1.91$ \\
\hline Good & 2.74 & $2.30-3.28$ \\
\hline Fair/Poor & 6.09 & $4.53-8.17$ \\
\hline
\end{tabular}

Table 11. Stress: Final Logistic Regression Model 
Table 11 Continued

\begin{tabular}{|l|c|c|}
\hline \multicolumn{3}{|l|}{ Exercise Status } \\
\hline Yes & Referent & -- \\
\hline No/Don't Know & 1.75 & $1.52-2.03$ \\
\hline Smoking Status \\
\hline Never Smoker & Referent & -- \\
\hline Former/Ever Smoker & 1.34 & $1.17-1.54$ \\
\hline Current Smoker & 1.37 & $1.18-1.59$ \\
\hline Age & 0.97 & $0.96-0.97$ \\
\hline
\end{tabular}

After adjustment for all other variables in the model, the odds of stress among Paramedics were $1.32(95 \% \mathrm{CI}=1.23-1.42)$ times the odds of stress among EMT-Basics. With respect to service type, EMS professionals in a county or municipal service $(\mathrm{OR}=1.28,95 \% \mathrm{CI}=1.07-1.51)$, and those in a private service $(\mathrm{OR}=1.35,95 \% \mathrm{CI}=1.16$ 1.56) had a greater odds of being stressed while those in a hospital-based service $(\mathrm{OR}=1.19,95 \% \mathrm{CI}=0.99-1.43)$ and those in "other" types of services $(\mathrm{OR}=1.05,95 \%$ $\mathrm{CI}=0.86-1.27)$ were not. When compared to those EMS professionals having two or fewer years of EMS experience, those having 3-7 years of experience were not at a statistically higher odds of being stressed $(\mathrm{OR}=1.1,95 \% \mathrm{CI}=0.89-1.36)$ while those having 8-15 years of experience and those EMS professionals having $\geq 16$ years of EMS experience had a higher odds of being stressed $(\mathrm{OR}=1.56,95 \% \mathrm{CI}=1.28-2.18$ and $\mathrm{OR}=1.67,95 \% \mathrm{CI}=1.28-2.18$, respectively). The odds of stress among minorities were $0.76(95 \% \mathrm{CI}=0.63-0.91)$ times the odds of stress among non-minorities. With respect to education level, EMS professionals having a college degree had a 1.22 (95\% $\mathrm{CI}=1.09$ 1.37) higher odds of being stressed. An increasing trend in the odds ratios was observed 
with respect to self-reported general health. When compared to those in excellent general health, those in very good general health $(\mathrm{OR}=1.60,95 \% \mathrm{CI}=1.35-1.91)$, those in good general health $(\mathrm{OR}=2.74,95 \% \mathrm{CI}=2.30-3.28)$, and those in fair/poor excellent health $(\mathrm{OR}=6.09,95 \% \mathrm{CI}=4.53-8.17)$ were more likely to be stressed. The odds of stress among those EMS professionals who did no exercise in the past month was $1.75(95 \% \mathrm{CI}=1.52$ 2.03) times the odds of stress among those EMS professionals who did exercise in the past month. Likewise, when compared to never smokers, former/ever smokers and current smokers had a higher odds of being stressed $(\mathrm{OR}=1.34,95 \% \mathrm{CI}=1.17-1.54$ and $\mathrm{OR}=1.37,95 \% \mathrm{CI}=1.18-1.58$, respectively). Lastly, with every one year increase in age of EMS professionals, a 0.97 decrease in the odds of being stressed was observed $(95 \%$ $\mathrm{CI}=0.96-0.97)$. All continuous variables were found to be linear in the logit. The Hosmer-Lemeshow goodness-of-fit test showed the stress model exhibited good fit $\left(\chi^{2}=6.62, p\right.$-value $\left.=0.5783\right)$. 


\section{Chapter 4: Discussion}

\subsection{Discussion of Results}

Based on study participant responses to the depression scale, the prevalence of depression among 23,451 nationally certified EMS professionals was found to be $6.8 \%(95 \%$ $\mathrm{CI}=6.4 \%-7.1 \%)$. The prevalence found in the current study appears to be consistent with other healthcare professions. With respect to nurses, prevalence of depression has been found to range from $7.9 \%$ to $33.0 \%{ }^{68-71}$ With respect to physicians, prevalence of depression has been found to range from 7.8\%-36.0\%. ${ }^{72-76}$ Among medical students, the prevalence of depression has been reported to be $28.6 \%{ }^{74}$

In the present study, the prevalence of anxiety among nationally certified EMS professionals was found to be $6.0 \%(95 \% \mathrm{CI}=5.7 \%-6.3 \%)$. With respect to nurses, previous literature suggests that the prevalence of anxiety in this occupation ranges from $22.3 \%-54.0 \%{ }^{70,71,77,78}$ With respect to physicians, the prevalence of anxiety has been reported to range from $2.2 \%-30.0 \% .^{74,75}$ The prevalence of anxiety among medical students has been reported to be $28.7 \%$. $^{74}$

Further, the prevalence of stress among the same nationally certified EMS professionals was $5.9 \%(95 \% \mathrm{CI}=5.6 \%-6.2 \%)$. With respect to nurses, past publications suggests that the prevalence of stress ranges from $7.0 \%-81 \%{ }^{78-81}$ Among physicians, the prevalence of stress has been found to range from $13 \%-48 \% .{ }^{82,83}$ 
When comparing the prevalence of depression, anxiety, and stress found in the current study to other healthcare professions, caution must be used. The current investigation focused on a national cohort of more than 20,000 individuals whereas the literature pertaining to other healthcare professions generally studied smaller cohorts and sometimes specialized fields of medicine such as emergency departments and intensive care.

Across all three logistic regression models, predictors that were simultaneously related to depression, anxiety, and stress were certification level, service type, general health status, exercise over the past month, smoking status, and age.

It is believed that Paramedics are more likely to be depressed, anxious, and stressed due to their job responsibilities and experience. Typically, Paramedics care for more critical patients, which likely increase their exposure to traumatic events. Likewise, all Paramedics must first become EMT-Basics before they can continue their training, and many EMS professionals work as EMT-Basics during their Paramedic training. It may be that those individuals who are Paramedics have been practicing in the prehospital field longer than those who are EMT-Basics, increasing their potential exposure to traumatic events. In addition, certification level has been found to be a predictor of mental disorders in EMS professionals in previous studies. ${ }^{53}$

Service type was a significant predictor in all three models. Individual service types may be related to specific types of traumatic exposures. For example, those service types engage in primarily 9-1-1 services may have a higher call volume to more critically ill or injured patients than those types of services that focus on non-emergent interfacility 
patient transfers. The scope of the current study did not allow investigation into the type of services provided by each EMS service.

Three variables related to self-reported health and wellness were found to be significant in all three models: general health, exercise, and smoking status. It is well documented that poor health and well being are risk factors for mental health disorders. ${ }^{84-}$ ${ }^{88}$ According to the Surgeon General, increased physical general health and activity improves mental health. ${ }^{89}$ In relation to EMS professionals, policy makers and EMS stakeholders should be encouraged to promote healthy lifestyles of EMS professionals.

Age was also found to be a significant predictor in each of the three models. This is believed to be related to experiences in the prehospital setting. Experience was a significant predictor in both the depression and stress model. This may be related to a higher risk of exposure to traumatic events the longer an EMS professional is in the prehospital setting. ${ }^{38}$ However, in studies of EMS professionals and stress levels, it was found that those EMS professionals with more years of experience in the prehospital field were less likely to be stressed. ${ }^{48,53}$ It has been posited that those who were adversely affected by stress changed careers. Further research is needed to assess years of experience and its relation to mental health in EMS. ${ }^{48,53}$

Also unique to the depression and stress models was education level and minority status. Those EMS professionals who possessed a college degree had elevated odds ratios of being stressed and depressed compared to those individuals who had less than a college degree. In addition, it was found those EMS professionals that self-reported minority status was associated with lesser odds of being depressed or anxious when 
compared to non-minorities. As indicated in previous investigations, these relationships have been observed in prior studies of EMS professionals. ${ }^{32,33,38,43,44}$ Future research is needed to determine why this relationship exists.

In only the depression and anxiety model, marital status was found to be a significant predictor. Those who were divorced, widowed, and separated and those who had never been married were more likely to be depressed and anxious when compared to those EMS professionals who were married. It has been reported that individuals who have a strong support system cope better with traumatic exposures, which may explain the findings in the current study. ${ }^{90}$ Further, it is of concern for those EMS professionals who do not have a support system outside of work, as it has been demonstrated that when among the general population, EMS professionals are less likely to seek help. ${ }^{46}$

Lastly, unique to only the depression model, gender was found to be a significant predictor. Surprisingly, when males and females were compared, females were less likely to be depressed. This finding does not support previous findings in the depression literature, which suggests that females may be more likely to seek help for mental disorders than males. ${ }^{41}{ }^{91}$ It is thought that females may be seeking help in coping more than males. Further, in the current study, females were more likely to be EMT-Basics, more likely to be married, exercise and be never smokers when compared to males. These characteristics may lead to less exposure to traumatic events, as well as lend to a better physical health and stronger support system. Unfortunately, it is beyond the scope of the current study to determine why females are less likely to be depressed, and future research should focus on this relationship. 
The EMS work-life characteristics found to be statistically significant with respect to depression, anxiety, and stress were certification level, service type, and years of experience. With respect to these three variables, little is modifiable and suggests that EMS professionals falling into these predictors be closely monitored for depression, anxiety or stress. Each certification level, each service type, and the years of experience an EMS professional possesses are invaluable to providing prehospital patient care. Therefore, future research should focus on the early detection and prevention of depression, anxiety, and stress among EMS professionals.

\subsection{Study Limitations}

As with any research study, this study has its limitations. Because this study focuses on a cohort of nationally certified EMS professionals, some may question whether the results are generalizable to the non-nationally certified EMS population. While national certification is required in 44 states in the U.S., not every state requires recertification on the national level. However, there are nationally certified EMS professionals in every state which lends to the argument of generalizability. Likewise, the cross-sectional design of this study only allows prevalence measures to be estimated in EMS professionals with certification expiring in 2009. Because of the study design, no inferences may be made to current incidence rates of depression, anxiety, or stress. Further, as with any survey, the collected data are self-reported and thus may introduce information bias into the study. This is because those individuals who are clinically depressed, anxious, or stressed may not have responded accurately to some or all aspects 
of the DASS-21 (such as "I felt I wasn't worth much as a person”). As such, the true number of EMS professionals determined by the DASS-21 to be clinically depressed, anxious, or stressed may be higher than the current study can estimate, leading to differential disease misclassification. Lastly, it will not be possible to determine cause(s) of depression, anxiety, and stress among EMS professionals. The cross-sectional design allows inferences related to prevalence of depression, anxiety, and stress to be made, as well as possible predictors of depression, anxiety, and stress in nationally certified EMS professionals.

\subsection{Concluding Remarks}

Utilizing data from the 2009 recertification survey, the current study was able to estimate the prevalence of depression, anxiety, and stress among a large cohort of nationally certified EMS professionals. Further, this study was able to identify statistically significant demographic and work-life characteristic variables that predicted depression, anxiety, and stress. Future research should attempt to follow EMS professionals prospectively to determine specific characteristics associated with occupational traumatic exposure and the development of clinical depression, anxiety, and stress. Likewise, specific research efforts should be undertaken to establish early recognition criteria in EMS professionals to ensure adequate and quick treatment of mental disorders. 


\section{References}

1. Dawson DE, Brown WE, Jr., Harwell TS. Assessment of nationally registered emergency medical technician certification training in the United States: the LEADS Project. Longitudinal Emergency Medical Technician Attributes Demographic Study. Prehosp Emerg Care. Jan-Mar 2003;7(1):114-119.

2. NREMT. Practice Analysis. NREMT. ; 2009.

3. NREMT. State Reciprocity. Available at:

https://www.nremt.org/nremt/about/stateReciprocityMap.asp. Accessed October, 2010.

4. NREMT. History of the NREMT. Available at: http://www.nremt.org/nremt/about/nremt_history.asp. Accessed October, 2010.

5. NREMT. EMT-Basic: Requirements for National EMS Certification. In: NREMT, ed. Columbus, $\mathrm{OH}$.

6. NREMT. Paramedic: Requirements for National EMS Certification. In: NREMT, ed. Columbus, $\mathrm{OH}$.

7. NREMT. EMT-Basic: Re-registration Requirements. Columbus, $\mathrm{OH}$.

8. NREMT. Paramedic: Re-registration Requirements. Columbus, OH.

9. BJ. MBW. Current Emergency Medical Services Workforce Issues in the United States. Journal of Emergency Management. 2004(2):19-26.

10. NREMT. NREMT Board of Directors Meeting. Columbus, OH; 2010:6-24.

11. Studnek JR, Fernandez AR. Characteristics of emergency medical technicians involved in ambulance crashes. Prehosp Disaster Med. Sep-Oct 2008;23(5):432437.

12. Lavender SA, Conrad KM, Reichelt PA, et al. Biomechanical analyses of paramedics simulating frequently performed strenuous work tasks. Appl Ergon. Apr 2000;31(2):167-177. 
13. Studnek JR, Crawford JM. Factors associated with back problems among emergency medical technicians. Am J Ind Med. Jun 2007;50(6):464-469.

14. Corbett SW, Grange JT, Thomas TL. Exposure of prehospital care providers to violence. Prehosp Emerg Care. Apr-Jun 1998;2(2):127-131.

15. Boal WL, Hales T, Ross CS. Blood-borne pathogens among firefighters and emergency medical technicians. Prehosp Emerg Care. Apr-Jun 2005;9(2):236247.

16. Studnek JR, Ferketich A, Crawford JM. On the job illness and injury resulting in lost work time among a national cohort of emergency medical services professionals. Am J Ind Med. Dec 2007;50(12):921-931.

17. Statistics BoL. Nonfatal Occupational Injuries and Illnesses Requiring Days Away From Work. Available at: http://www.bls.gov/news.release/osh2.nr0.htm. Accessed 5-9-2011, 2011.

18. Maguire BJ, Hunting KL, Guidotti TL, et al. Occupational injuries among emergency medical services personnel. Prehosp Emerg Care. Oct-Dec 2005;9(4):405-411.

19. Services. USDoHaH. Mental Health: A Report of the Surgeon General Executive Summary. . In: Services USDoHaH, ed. Rockville, MD: National Institute of Mental Health; 1999.

20. Murray CJ, Lopez AD. Global mortality, disability, and the contribution of risk factors: Global Burden of Disease Study. Lancet. May 17 1997;349(9063):14361442 .

21. Kessler RC, Nelson CB, McGonagle KA, et al. The epidemiology of co-occurring addictive and mental disorders: implications for prevention and service utilization. Am J Orthopsychiatry. Jan 1996;66(1):17-31.

22. Regier DA, Narrow WE, Rae DS, et al. The de facto US mental and addictive disorders service system. Epidemiologic catchment area prospective 1-year prevalence rates of disorders and services. Arch Gen Psychiatry. Feb 1993;50(2):85-94.

23. CDC. Depression. Available at: http://www.cdc.gov/Features/dsDepression/. Accessed November 1, 2010. 
24. Kahn AP FJ. The Encyclopedia of Mental Health. Second ed. New York City, NY: Facts on File, INC; 2001.

25. Kraly. Brain Science and Psychological Disorders. New York, NY: W. W. Norton \& Company; 2006.

26. WHO. Mental Health: Depression. World Health Organization. Available at: http://www.who.int/mental health/management/depression/definition/en/index.ht ml. Accessed 12-1-2010, 2010.

27. Barry Levy DW, Sherry Baron, Rosemary Sokas. . Occupational and Environmental Health. 5th Edition ed. Philadelphia, PA: Lippincott Williams and Wilkins; 2006.

28. Lubin G, Sids C, Vishne T, et al. Acute stress disorder and post-traumatic stress disorder among medical personnel in Judea and Samaria areas in the years 20002003. Mil Med. Apr 2007;172(4):376-378.

29. CDC. Coping with Stress. Available at: http://www.cdc.gov/features/handlingstress/. Accessed November 1, 2010.

30. Hagh-Shenas H, Goodarzi MA, Dehbozorgi G, et al. Psychological consequences of the Bam earthquake on professional and nonprofessional helpers. J Trauma Stress. Oct 2005;18(5):477-483.

31. Regehr C, Goldberg G, Hughes J. Exposure to human tragedy, empathy, and trauma in ambulance paramedics. Am J Orthopsychiatry. Oct 2002;72(4):505513.

32. Revicki DA, Gershon RR. Work-related stress and psychological distress in emergency medical technicians. J Occup Health Psychol. Oct 1996;1(4):391-396.

33. Aasa U, Brulin C, Angquist KA, et al. Work-related psychosocial factors, worry about work conditions and health complaints among female and male ambulance personnel. Scand J Caring Sci. Sep 2005;19(3):251-258.

34. Nirel N, Goldwag R, Feigenberg Z, et al. Stress, work overload, burnout, and satisfaction among paramedics in Israel. Prehosp Disaster Med. Nov-Dec 2008;23(6):537-546.

35. Beaton R, Murphy S, Johnson C, et al. Exposure to duty-related incident stressors in urban firefighters and paramedics. J Trauma Stress. Oct 1998;11(4):821-828. 
36. Jonsson A, Segesten K. The meaning of traumatic events as described by nurses in ambulance service. Accid Emerg Nurs. Jul 2003;11(3):141-152.

37. Clohessy S, Ehlers A. PTSD symptoms, response to intrusive memories and coping in ambulance service workers. Br J Clin Psychol. Sep 1999;38 ( Pt 3):251265.

38. Moran C, Britton NR. Emergency work experience and reactions to traumatic incidents. J Trauma Stress. Oct 1994;7(4):575-585.

39. Ahern M, Kovats RS, Wilkinson P, et al. Global health impacts of floods: epidemiologic evidence. Epidemiol Rev. 2005;27:36-46.

40. Voelker R. Katrina's impact on mental health likely to last years. JAMA. Oct 5 2005;294(13):1599-1600.

41. Xiong X, Harville EW, Mattison DR, et al. Hurricane Katrina experience and the risk of post-traumatic stress disorder and depression among pregnant women. $\mathrm{Am}$ J Disaster Med. May-Jun;5(3):181-187.

42. Nortje C, Roberts CB, Moller AT. Judgement of risk in traumatized and nontraumatized emergency medical service personnel. Psychol Rep. Dec 2004;95(3 Pt 2):1119-1128.

43. Essex B, Scott LB. Chronic stress and associated coping strategies among volunteer EMS personnel. Prehosp Emerg Care. Jan-Mar 2008;12(1):69-75.

44. Sloan IH, Rozensky RH, Kaplan L, et al. A shooting incident in an elementary school: effects of worker stress on public safety, mental health, and medical personnel. J Trauma Stress. Oct 1994;7(4):565-574.

45. Mental health status of World Trade Center rescue and recovery workers and volunteers - New York City, July 2002-August 2004. MMWR Morb Mortal Wkly Rep. Sep 10 2004;53(35):812-815.

46. Sterud T, Hem E, Ekeberg O, et al. Health problems and help-seeking in a nationwide sample of operational Norwegian ambulance personnel. BMC Public Health. 2008;8:3.

47. Williams CL, Solomon SD, Bartone P. Primary prevention in aircraft disasters. Integrating research and practice. Am Psychol. Sep 1988;43(9):730-739. 
48. Cydulka RK, Emerman CL, Shade B, et al. Stress levels in EMS personnel: a longitudinal study with work-schedule modification. Acad Emerg Med. May-Jun 1994;1(3):240-246.

49. Hammer JS, Mathews JJ, Lyons JS, et al. Occupational stress within the paramedic profession: an initial report of stress levels compared to hospital employees. Ann Emerg Med. May 1986;15(5):536-539.

50. MMWR. Injuries and Illnesses Among New York City Fire Department Rescue Workers After Responding to the World Trade Center Attacks. 2002.

51. Alexander DA, Klein S. Ambulance personnel and critical incidents: impact of accident and emergency work on mental health and emotional well-being. $\mathrm{Br} J$ Psychiatry. Jan 2001;178(1):76-81.

52. Rodgers LM. A five year study comparing early retirements on medical grounds in ambulance personnel with those in other groups of health service staff. Part II: Causes of retirements. Occup Med (Lond). Feb 1998;48(2):119-132.

53. Cydulka RK, Emerman CL, Shade B, et al. Stress levels in EMS personnel: a national survey. Prehosp Disaster Med. Apr-Jun 1997;12(2):136-140.

54. NREMT. History of the National Registry of EMTs. Available at: http://www.nremt.org. Accessed September 1, 2010.

55. Lerner EB, Fernandez AR, Shah MN. Do emergency medical services professionals think they should participate in disease prevention? Prehosp Emerg Care. Jan-Mar 2009;13(1):64-70.

56. Studnek JR, Bentley M, Crawford JM, et al. An Assessment of Key Health Indicators among Emergency Medical Services Professionals. Prehosp Emerg Care. Sep 3 2009:1.

57. Studnek JR, Ferketich A. Organizational policy and other factors associated with emergency medical technician seat belt use. J Safety Res. 2007;38(1):1-8.

58. Studnek JR, Fernandez AR. Organizational description and emergency preparedness of Nationally Registered First Responders. Prehosp Disaster Med. May-Jun 2008;23(3):250-255.

59. Studnek JR, Fernandez AR, Margolis GS, et al. Physician medical oversight in emergency medical services: where are we? Prehosp Emerg Care. Jan-Mar 2009;13(1):53-58. 
60. PF LSL. Manual for the Depression Anxiety Stress Scales. 2nd ed.: Sydney: Psychology Foundations; 2005.

61. Antony MM BP, Cox BJ, Enns MW, Swinson RP. Pyschometric Properties of the 42-Item and 21-Item Versions of the Depression Anxiety Stress Scales in Clinical Groups and a Community Sample. American Psychological Association. 1998;10(2):176-181.

62. Gloster AT, Rhoades HM, Novy D, et al. Psychometric properties of the Depression Anxiety and Stress Scale-21 in older primary care patients. $J$ Affect Disord. Oct 2008;110(3):248-259.

63. Henry JD, Crawford JR. The short-form version of the Depression Anxiety Stress Scales (DASS-21): construct validity and normative data in a large non-clinical sample. Br J Clin Psychol. Jun 2005;44(Pt 2):227-239.

64. Nieuwenhuijsen K, de Boer AG, Verbeek JH, et al. The Depression Anxiety Stress Scales (DASS): detecting anxiety disorder and depression in employees absent from work because of mental health problems. Occup Environ Med. Jun 2003;60 Suppl 1:i77-82.

65. Norton PJ. Depression Anxiety and Stress Scales (DASS-21): psychometric analysis across four racial groups. Anxiety Stress Coping. Sep 2007;20(3):253265.

66. Tully PJ, Zajac IT, Venning AJ. The structure of anxiety and depression in a normative sample of younger and older Australian adolescents. J Abnorm Child Psychol. Jul 2009;37(5):717-726.

67. Crawford JR, Garthwaite PH, Lawrie CJ, et al. A convenient method of obtaining percentile norms and accompanying interval estimates for self-report mood scales (DASS, DASS-21, HADS, PANAS, and sAD). Br J Clin Psychol. Jun 2009;48(Pt 2):163-180.

68. Lin HS, Probst JC, Hsu YC. Depression among female psychiatric nurses in southern Taiwan: main and moderating effects of job stress, coping behaviour and social support. J Clin Nurs. Aug;19(15-16):2342-2354.

69. Whang W, Kubzansky LD, Kawachi I, et al. Depression and risk of sudden cardiac death and coronary heart disease in women: results from the Nurses' Health Study. J Am Coll Cardiol. Mar 17 2009;53(11):950-958. 
70. Ardekani ZZ, Kakooei H, Ayattollahi SM, et al. Prevalence of mental disorders among shift work hospital nurses in Shiraz, Iran. Pak J Biol Sci. Jun 15 2008;11(12):1605-1609.

71. Tabolli S, Ianni A, Renzi C, et al. [Job satisfaction, burnout and stress amongst nursing staff: a survey in two hospitals in Rome]. G Ital Med Lav Ergon. Jan-Mar 2006;28(1 Suppl 1):49-52.

72. Albuquerque J, Deshauer D, Fergusson D, et al. Recurrence rates in Ontario physicians monitored for major depression and bipolar disorder. Can J Psychiatry. Nov 2009;54(11):777-782.

73. Schwenk TL, Gorenflo DW, Leja LM. A survey on the impact of being depressed on the professional status and mental health care of physicians. J Clin Psychiatry. Apr 2008;69(4):617-620.

74. Ahmed I, Banu H, Al-Fageer R, et al. Cognitive emotions: depression and anxiety in medical students and staff. J Crit Care. Sep 2009;24(3):e1-7.

75. Buddeberg-Fischer B, Stamm M, Buddeberg C, et al. [Anxiety and depression in residents - results of a Swiss longitudinal study]. Z Psychosom Med Psychother. 2009;55(1):37-50.

76. Compton MT, Frank E. Mental health concerns among Canadian physicians: results from the 2007-2008 Canadian Physician Health Study. Compr Psychiatry. Dec 1.

77. Cooke M, Holzhauser K, Jones M, et al. The effect of aromatherapy massage with music on the stress and anxiety levels of emergency nurses: comparison between summer and winter. J Clin Nurs. Sep 2007;16(9):1695-1703.

78. Meeusen V, K VAND, Brown-Mahoney C, et al. Burnout, psychosomatic symptoms and job satisfaction among Dutch nurse anaesthetists: a survey. Acta Anaesthesiol Scand. May;54(5):616-621.

79. Von Rueden KT, Hinderer KA, McQuillan KA, et al. Secondary traumatic stress in trauma nurses: prevalence and exposure, coping, and personal/environmental characteristics. J Trauma Nurs. Oct-Dec;17(4):191-200.

80. Kashani M, Eliasson A, Chrosniak L, et al. Taking aim at nurse stress: a call to action. Mil Med. Feb;175(2):96-100.

81. Preto VA, Pedrao LJ. [Stress among nurses who work at the intensive care unit]. Rev Esc Enferm USP. Dec 2009;43(4):841-848. 
82. Vanagas G, Bihari-Axelsson S. The factors associated to psychosocial stress among general practitioners in Lithuania. Cross-sectional study. BMC Health Serv Res. 2005;5:45.

83. Perez-Guzman ID, Zonana-Nacach A, Valles-Medina AM. [Stress levels in health care workers from primary care units]. Rev Med Inst Mex Seguro Soc. Sep-Oct 2009;47(5):575-579.

84. Asztalos M, De Bourdeaudhuij I, Cardon G. The relationship between physical activity and mental health varies across activity intensity levels and dimensions of mental health among women and men. Public Health Nutr. Aug;13(8):1207-1214.

85. Rosen-Reynoso M, Alegria M, Chen CN, et al. The relationship between obesity and psychiatric disorders across ethnic and racial minority groups in the United States. Eat Behav. Jan;12(1):1-8.

86. Bowden JA, Miller CL, Hiller JE. Smoking and mental illness: a population study in South Australia. Aust N Z J Psychiatry. Dec 13.

87. Bertheussen GF, Romundstad PR, Landmark T, et al. Associations between Physical Activity and Physical and Mental Health -A HUNT 3 Study. Med Sci Sports Exerc. Dec 1.

88. Marinho V, Blay SL, Andreoli SB, et al. A prevalence study of current tobacco smoking in later life community and its association with sociodemographic factors, physical health and mental health status. Soc Psychiatry Psychiatr Epidemiol. Jun 2008;43(6):490-497.

89. Physical Activity and Health: A Surgeon General's Report. In: HHS C, National Center for Chronic Disease Prevention and Health Promotion, The President's Council on Physical Fitness and Sports, ed. Washington, DC; 1996.

90. Sterud T, Hem E, Ekeberg O, et al. Occupational stressors and its organizational and individual correlates: a nationwide study of Norwegian ambulance personnel. BMC Emerg Med. 2008;8:16.

91. Y TDDK-OD. Gender and self-reported mental health problems: predictors of help seeking from a general practitioner. British Journal of Health Psychology. 2010;15:213-228. 


\section{APPENDIX A:}

National Registry of Emergency Medical Technicians 2009 Recertification Survey 
Dear Emergency Medical Services Colleague:

The National Registry of EMTs (NREMT) is currently conducting a survey of EMS professionals. This study hopes to describe the health satus of EMS professionals. Answers to these questions may help direct future research and policy related to the hesith and wellness of EMS professionals. We expect that it will take you less than 10 minutes to complete this entire survey.

If you wish to participate in this research project please complete the following survey and return it to the NREMT with your re-certification paperwork. Your privacy is important to us, thus the survey wil be separated from all re-certification materials prior to processing your re-certification or recording your survey responses

There are no foreseeable risks in participation. Your participation in this project is entirely voluntary. The NREMT does not mandaterrequire participation in this project, as such there are no penalties associated with not participating

If you have any questions about this project, please contact Melissa Bentiey. EMS Research Fellow at (614)-888-4484 or mbentley@rremt orn If you have any questions regarding your rights as a project participant you may contact Dr. Gregg Margolis. NREMT Associate Director, at (614)-8884484 or greggm@nremt.org. Thank you for your participation.

NREMT RECERTIFICATION SURVEY

USE NO. 2 PENCIL - BUBBLE IN THE SELECTED RESPONSE

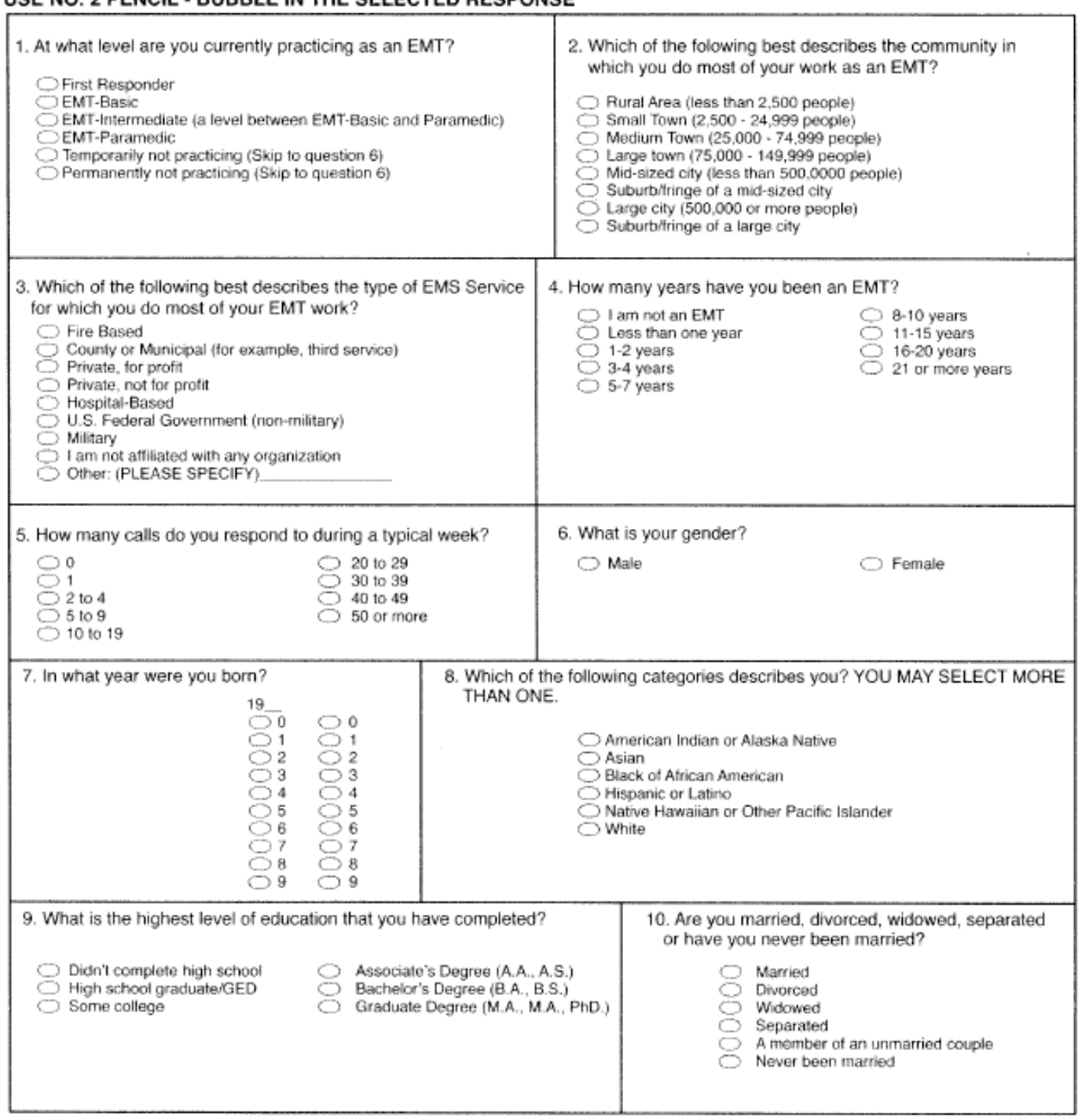

Page 3 


\section{- nREMt Recertification suRvey - USE NO. 2 PENCIL - BUBBLE IN THE SELECTED RESPONSE \\ $=$}

11. Would you say that in general your health is:
$\bigcirc$ Excellent
$\bigcirc$ Very Good
$\bigcirc$ Good
○air
Poor

12. We are concerned about the health of EMS providers and recognize that it is difficult to maintain a regular fitness and diet schedule while in EMS. We are asking your height and weight to be able to calculate body mass index (BMI) as an objective indicator of overall health.

What is your height?

What is your weight in pounds?

$\begin{array}{lll}\bigotimes & 4 & \text { Feet } \\ & 5 & \\ & 6 & \\ \bigcirc & 7 & \end{array}$

$\bigcirc 0$ inches

$\bigodot_{2}$

$\square_{3}^{2}$

$\bigotimes^{3} 4$

$8 \begin{aligned} & 4 \\ & 5 \\ & 6\end{aligned}$

$\bigcirc 7$

$\bigcirc$

$8 \begin{array}{ll}10 \\ 11\end{array}$

13. During the past 30 days, other than your regular job, did you participate in any physical activities or exercises such as running, calisthenics, golf, walking for exercise, or other sports?

=

- $\bigcirc$ Yes $\bigcirc$ No $\bigcirc$ Don't Know

- least 20 minutes of moderate to vigorous-intensity physical

- activity above the usual activity at work or home?

- $\begin{array}{llllllll}01 & 02 & 0^{3} & 0^{4} & 0^{5} & 06 & 07\end{array}$

14. On average how many days a week do you engage in at least 30 minutes of moderate-intensity physical activity above the usual activity at work or home?

$\begin{array}{lll}0 & 0 & 0 \\ 1 & 0 & 0\end{array}$

$\square_{3} \bigcirc 2 \bigcirc 2$

$\bigcirc_{4}^{3} \bigcirc \bigcirc_{4}^{3} \bigcirc 3$

$\bigcirc 5 \bigcirc 5$

$\bigotimes_{7}^{6} \bigcirc 7$

$\bigcirc_{9}^{8} \bigcirc 8$

17. Do you now smoke cigarettes every day, some days, or not at all?

$\bigcirc$ Every day $\bigcirc$ Some days $\bigcirc$ Not at all

18. Please read each statement and select the option which indicates how much the statement applied to you over the past week. There are no right or wrong answers. Do not spend too much time on any statement.

\begin{tabular}{|c|c|c|c|c|}
\hline & $\begin{array}{l}\text { Did not } \\
\text { apply to } \\
\text { me at all }\end{array}$ & $\begin{array}{l}\text { Applied to me to } \\
\text { some degree, or } \\
\text { some of the time }\end{array}$ & \begin{tabular}{|c|} 
Applied to me to a \\
considerable degree, or \\
a good part of the time
\end{tabular} & $\begin{array}{l}\text { Applied to me } \\
\text { very much, or } \\
\text { most of the time }\end{array}$ \\
\hline I found it hard to wind down & O & $\overline{0}$ & O & 0 \\
\hline I was aware of dryness of my mouth & 0 & $\delta$ & 0 & O \\
\hline I couldn't seem to experience any positive feeling at all & 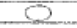 & $\varnothing$ & 0. & 0 \\
\hline $\begin{array}{l}\text { Texperienced breathing difficulty (eg. excessively rapid breathing, breathlessness in } \\
\text { the absence of physical oxertion) }\end{array}$ & 0 & 0 & $D$ & 0 \\
\hline If found it difficult to work up the initiative to do things & 0 & 5 & & 5 \\
\hline I terdided to over-react to situations & 5 & D & $\Omega$ & 0 \\
\hline I experienced trembling (eg. in the hands) & 0 & כ & 0 & 5 \\
\hline If felt that I was using a lot of nervous energy & 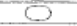 & S & D & So \\
\hline I was worried about situations in which I might panic and make a tool of myself & 0 & 0 & $\square$ & 5 \\
\hline If felt that I had nothing to look forward to & Q & 5 & P & 5 \\
\hline it found myself getting agitated & $\sigma$ & D & o & O \\
\hline I found it difficult to relax & 0 & 0 & 0 & ठ \\
\hline I fell down-hearted and blue & ( & 5 & Q & 0 \\
\hline I was intolerant of anything that kept me from getting on with what I was doing & 0 & S & O & C \\
\hline I felt I was close to panic & Q. & 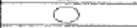 & 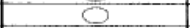 & 5 \\
\hline I was unable to become enthusiastic about anything & 0 & $\varnothing$ & D & 0 \\
\hline I telt I wasn't worth much as a person & 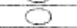 & 5 & 0 & 0 \\
\hline I felt that I was rather touchy & 0 & $\delta$ & 0 & 5 \\
\hline $\begin{array}{l}\text { I was aware of the action of my heart in the absence of physical exertion (eg. sense } \\
\text { of heart rate increase, heart missing a beat) }\end{array}$ & 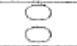 & 8 & $\bigcirc$ & 8 \\
\hline If felt scared without any good reason & 0 & $\varnothing$ & 0 & 0 \\
\hline I felt that life was meaningless & 0 & 0 & 0 & \\
\hline
\end{tabular}

Ifelt that life was meaningless

16. Have you smoked at least 100 cigarettes in your entire life? Note: 5 packs $=100$ cigarettes
Ores
$\subseteq$ No
Don't Know

三

$=$

三 


\section{APPENDIX B}

Depression Anxiety and Stress Scale-21 Question Scoring 
DASS-21 Score Interpretation ${ }^{60}$

\begin{tabular}{|l|c|c|c|}
\hline & Depression & Anxiety & Stress \\
\hline Normal & $0-9$ & $0-7$ & $0-14$ \\
\hline Mild & $10-13$ & $8-9$ & $15-18$ \\
\hline Moderate & $14-20$ & $10-14$ & $19-25$ \\
\hline Severe & $21-27$ & $15-19$ & $26-33$ \\
\hline Extremely Severe & $28+$ & $20+$ & $34+$ \\
\hline
\end{tabular}


APPENDIX C

Assessment of Confounding: Backwards Elimination 


\section{Depression}

\begin{tabular}{|l|c|c|c|}
\hline & Community Size & Call Volume & BMI \\
\hline Model Variables & $\%$ Change & $\%$ Change & $\%$ Change \\
\hline Certification Level & $0.77 \%$ & $1.55 \%$ & $0.00 \%$ \\
\hline Service Type: County & $0.00 \%$ & $0.00 \%$ & $0.00 \%$ \\
\hline Service Type: Private & $0.00 \%$ & $0.00 \%$ & $0.00 \%$ \\
\hline Service Type: Hospital & $0.00 \%$ & $0.00 \%$ & $0.00 \%$ \\
\hline Service Type: Other & $2.83 \%$ & $3.77 \%$ & $0.94 \%$ \\
\hline Experience: 3-7 Years & $0.00 \%$ & $0.00 \%$ & $0.00 \%$ \\
\hline Experience: 8-15 Years & $0.00 \%$ & $0.00 \%$ & $0.00 \%$ \\
\hline Experience: 16+ Years & $0.78 \%$ & $0.00 \%$ & $0.78 \%$ \\
\hline Gender & $0.00 \%$ & $1.18 \%$ & $1.18 \%$ \\
\hline Age & $0.00 \%$ & $0.00 \%$ & $0.00 \%$ \\
\hline Race & $1.22 \%$ & $0.00 \%$ & $0.00 \%$ \\
\hline Education Level & $0.00 \%$ & $0.86 \%$ & $0.00 \%$ \\
\hline $\begin{array}{l}\text { Marital Status: } \\
\text { Divorced/Widowed Separated }\end{array}$ & $0.00 \%$ & $0.64 \%$ & $0.64 \%$ \\
\hline $\begin{array}{l}\text { Marital Status: Never been } \\
\text { married }\end{array}$ & $0.00 \%$ & $0.00 \%$ & $0.65 \%$ \\
\hline General Health: Very Good & $0.50 \%$ & $0.00 \%$ & $1.01 \%$ \\
\hline General Health: Good & $0.00 \%$ & $0.28 \%$ & $2.28 \%$ \\
\hline General Health: Fair/Poor & $0.00 \%$ & $0.63 \%$ & $4.17 \%$ \\
\hline Exercise & $0.56 \%$ & $0.00 \%$ & $0.56 \%$ \\
\hline Smoking: Former/Ever & $0.00 \%$ & $0.00 \%$ & $0.00 \%$ \\
\hline Smoking: Current & $0.81 \%$ & $0.81 \%$ & $0.00 \%$ \\
\hline
\end{tabular}

** Community Size Removed as Possible Confounder 


\begin{tabular}{|l|c|c|}
\hline \multicolumn{2}{|c|}{ Second Round: Depression } \\
\hline & Call Volume & BMI \\
\hline Model Variables & $\%$ Change & $\%$ Change \\
\hline Certification Level & $1.56 \%$ & $0.00 \%$ \\
\hline Service Type: County & $2.94 \%$ & $0.74 \%$ \\
\hline Service Type: Private & $0.00 \%$ & $0.00 \%$ \\
\hline Service Type: Hospital & $0.00 \%$ & $0.00 \%$ \\
\hline Service Type: Other & $2.83 \%$ & $0.00 \%$ \\
\hline Experience: 3-7 Years & $0.00 \%$ & $0.00 \%$ \\
\hline Experience: 8-15 Years & $0.89 \%$ & $0.89 \%$ \\
\hline Experience: 16+ Years & $0.78 \%$ & $0.00 \%$ \\
\hline Gender & $1.18 \%$ & $1.18 \%$ \\
\hline Age & $0.00 \%$ & $0.00 \%$ \\
\hline Race & $1.23 \%$ & $1.23 \%$ \\
\hline Education Level & $0.86 \%$ & $0.86 \%$ \\
\hline Marital Status: Divorced/Widowed Separated & $0.64 \%$ & $0.00 \%$ \\
\hline Marital Status: Never been married & $0.00 \%$ & $0.65 \%$ \\
\hline General Health: Very Good & $0.50 \%$ & $0.50 \%$ \\
\hline General Health: Good & $0.28 \%$ & $2.56 \%$ \\
\hline General Health: Fair/Poor & $0.52 \%$ & $4.38 \%$ \\
\hline Exercise & $0.00 \%$ & $1.12 \%$ \\
\hline Smoking: Former/Ever & $0.00 \%$ & $0.00 \%$ \\
\hline Smoking: Current & $0.00 \%$ & $0.81 \%$ \\
\hline
\end{tabular}

**Call Volume Removed as Possible Confounder 


\begin{tabular}{|l|c|}
\hline \multicolumn{2}{|c|}{ Third Round: Depression } \\
\hline & BMI \\
\hline Certification Level & $\%$ Change \\
\hline Service Type: County & $0.00 \%$ \\
\hline Service Type: Private & $0.00 \%$ \\
\hline Service Type: Hospital & $0.76 \%$ \\
\hline Service Type: Other & $0.00 \%$ \\
\hline Experience: 3-7 Years & $0.97 \%$ \\
\hline Experience: 8 -15 Years & $0.00 \%$ \\
\hline Experience: 16+ Years & $0.00 \%$ \\
\hline Gender & $0.79 \%$ \\
\hline Age & $0.00 \%$ \\
\hline Race & $0.00 \%$ \\
\hline Education Level & $0.00 \%$ \\
\hline Marital Status: Divorced/Widowed Separated & $0.00 \%$ \\
\hline Marital Status: Never been married & $0.00 \%$ \\
\hline General Health: Very Good & $1.65 \%$ \\
\hline General Health: Good & $1.01 \%$ \\
\hline General Health: Fair/Poor & $2.57 \%$ \\
\hline Exercise & $4.51 \%$ \\
\hline Smoking: Former/Ever & $0.56 \%$ \\
\hline Smoking: Current & $0.00 \%$ \\
\hline
\end{tabular}

** BMI Removed as Possible Confounder 


\section{Anxiety}

\begin{tabular}{|c|c|c|c|c|c|c|c|}
\hline \multicolumn{8}{|c|}{ First Round: Anxiety } \\
\hline & $\begin{array}{c}\text { Community } \\
\text { Size }\end{array}$ & Experience & $\begin{array}{c}\text { Call } \\
\text { Volume }\end{array}$ & Gender & Race & $\begin{array}{c}\text { Education } \\
\text { Level }\end{array}$ & BMI \\
\hline & $\%$ Change & $\%$ Change & $\begin{array}{c}\% \\
\text { Change }\end{array}$ & $\begin{array}{c}\% \\
\text { Change }\end{array}$ & $\begin{array}{c}\% \\
\text { Change }\end{array}$ & $\%$ Change & $\begin{array}{c}\% \\
\text { Change }\end{array}$ \\
\hline Certification Level & $0.88 \%$ & $0.00 \%$ & $0.88 \%$ & $0.00 \%$ & $2.62 \%$ & $0.88 \%$ & $0.00 \%$ \\
\hline $\begin{array}{l}\text { Service Type: } \\
\text { County }\end{array}$ & $0.61 \%$ & $0.00 \%$ & $0.61 \%$ & $2.42 \%$ & $0.00 \%$ & $0.00 \%$ & $0.00 \%$ \\
\hline $\begin{array}{l}\text { Service Type: } \\
\text { Private }\end{array}$ & $0.00 \%$ & $0.63 \%$ & $1.26 \%$ & $2.52 \%$ & $0.63 \%$ & $0.63 \%$ & $0.63 \%$ \\
\hline $\begin{array}{l}\text { Service Type: } \\
\text { Hospital }\end{array}$ & $0.68 \%$ & $0.00 \%$ & $0.68 \%$ & $2.74 \%$ & $0.00 \%$ & $0.00 \%$ & $0.00 \%$ \\
\hline $\begin{array}{l}\text { Service Type: } \\
\text { Other }\end{array}$ & $1.01 \%$ & $0.00 \%$ & $2.02 \%$ & $1.01 \%$ & $0.00 \%$ & $0.00 \%$ & $1.01 \%$ \\
\hline Age & $0.00 \%$ & $0.00 \%$ & $0.00 \%$ & $0.00 \%$ & $0.00 \%$ & $0.00 \%$ & $0.00 \%$ \\
\hline $\begin{array}{l}\text { Marital Status: } \\
\text { Divorced/Widowed } \\
\text { Separated }\end{array}$ & $0.00 \%$ & $0.00 \%$ & $0.00 \%$ & $1.60 \%$ & $0.00 \%$ & $0.00 \%$ & $0.00 \%$ \\
\hline $\begin{array}{l}\text { Marital Status: } \\
\text { Never been } \\
\text { married }\end{array}$ & $0.00 \%$ & $0.00 \%$ & $0.81 \%$ & $1.63 \%$ & $0.81 \%$ & $1.63 \%$ & $0.00 \%$ \\
\hline $\begin{array}{l}\text { General Health: } \\
\text { Very Good }\end{array}$ & $0.00 \%$ & $0.00 \%$ & $0.55 \%$ & $0.55 \%$ & $0.00 \%$ & $0.55 \%$ & $0.55 \%$ \\
\hline $\begin{array}{l}\text { General Health: } \\
\text { Good }\end{array}$ & $0.26 \%$ & $0.26 \%$ & $0.26 \%$ & $0.52 \%$ & $0.00 \%$ & $0.78 \%$ & $1.82 \%$ \\
\hline $\begin{array}{l}\text { General Health: } \\
\text { Fair/Poor }\end{array}$ & $0.00 \%$ & $0.09 \%$ & $1.22 \%$ & $0.28 \%$ & $0.09 \%$ & $0.75 \%$ & $3.37 \%$ \\
\hline Exercise & $0.00 \%$ & $0.00 \%$ & $0.00 \%$ & $0.65 \%$ & $0.00 \%$ & $0.65 \%$ & $0.00 \%$ \\
\hline $\begin{array}{l}\text { Smoking: } \\
\text { Former/Ever }\end{array}$ & $0.00 \%$ & $0.00 \%$ & $0.00 \%$ & $0.00 \%$ & $0.00 \%$ & $0.74 \%$ & $0.00 \%$ \\
\hline Smoking: Current & $0.78 \%$ & $0.00 \%$ & 0.78 & $0.78 \%$ & $0.00 \%$ & $1.56 \%$ & $0.00 \%$ \\
\hline
\end{tabular}

**Years of Experience Removed as Possible Confounder 


\begin{tabular}{|c|c|c|c|c|c|c|}
\hline \multicolumn{7}{|c|}{ Second Round: Anxiety } \\
\hline & $\begin{array}{l}\text { Community } \\
\text { Size }\end{array}$ & $\begin{array}{c}\text { Call } \\
\text { Volume }\end{array}$ & Gender & Race & $\begin{array}{c}\text { Education } \\
\text { Level }\end{array}$ & BMI \\
\hline & $\%$ Change & $\%$ Change & $\begin{array}{c}\% \\
\text { Change }\end{array}$ & $\begin{array}{c}\% \\
\text { Change }\end{array}$ & $\begin{array}{c}\% \\
\text { Change }\end{array}$ & $\begin{array}{c}\% \\
\text { Change }\end{array}$ \\
\hline Certification Level & $0.00 \%$ & $0.88 \%$ & $0.00 \%$ & $2.62 \%$ & $0.88 \%$ & $0.88 \%$ \\
\hline $\begin{array}{l}\text { Service Type: } \\
\text { County }\end{array}$ & $0.61 \%$ & $0.61 \%$ & $2.42 \%$ & $0.00 \%$ & $0.00 \%$ & $0.00 \%$ \\
\hline $\begin{array}{l}\text { Service Type: } \\
\text { Private }\end{array}$ & $0.00 \%$ & $0.63 \%$ & $1.87 \%$ & $0.00 \%$ & $0.00 \%$ & $0.00 \%$ \\
\hline $\begin{array}{l}\text { Service Type: } \\
\text { Hospital }\end{array}$ & $0.68 \%$ & $0.68 \%$ & $2.74 \%$ & $0.00 \%$ & $0.00 \%$ & $0.00 \%$ \\
\hline $\begin{array}{l}\text { Service Type: } \\
\text { Other }\end{array}$ & $1.01 \%$ & $2.20 \%$ & $1.01 \%$ & $0.00 \%$ & $0.00 \%$ & $0.00 \%$ \\
\hline Age & $0.00 \%$ & $0.00 \%$ & $0.00 \%$ & $0.00 \%$ & $0.00 \%$ & $0.00 \%$ \\
\hline $\begin{array}{l}\text { Marital Status: } \\
\text { Divorced, } \\
\text { Widowed } \\
\text { Separated }\end{array}$ & $0.00 \%$ & $0.00 \%$ & $1.60 \%$ & $0.00 \%$ & $0.00 \%$ & $0.00 \%$ \\
\hline $\begin{array}{l}\text { Marital Status: } \\
\text { Never been } \\
\text { married }\end{array}$ & $0.00 \%$ & $0.81 \%$ & $1.63 \%$ & $1.60 \%$ & $0.81 \%$ & $0.00 \%$ \\
\hline $\begin{array}{l}\text { General Health: } \\
\text { Very Good }\end{array}$ & $0.00 \%$ & $0.55 \%$ & $0.55 \%$ & $0.00 \%$ & $0.55 \%$ & $0.55 \%$ \\
\hline $\begin{array}{l}\text { General Health: } \\
\text { Good }\end{array}$ & $0.00 \%$ & $0.52 \%$ & $0.26 \%$ & $0.00 \%$ & $1.04 \%$ & $1.82 \%$ \\
\hline $\begin{array}{l}\text { General Health: } \\
\text { Fair/Poor }\end{array}$ & $0.09 \%$ & $1.31 \%$ & $0.19 \%$ & $0.00 \%$ & $0.75 \%$ & $3.46 \%$ \\
\hline Exercise & $0.00 \%$ & $0.00 \%$ & $0.65 \%$ & $0.00 \%$ & $0.00 \%$ & $0.65 \%$ \\
\hline $\begin{array}{l}\text { Smoking: } \\
\text { Former/Ever }\end{array}$ & $0.00 \%$ & $0.00 \%$ & $0.00 \%$ & $0.00 \%$ & $0.74 \%$ & $0.00 \%$ \\
\hline Smoking: Current & $0.00 \%$ & $0.78 \%$ & $0.78 \%$ & $0.00 \%$ & $1.56 \%$ & $0.78 \%$ \\
\hline
\end{tabular}

**Community Size Removed as Possible Confounder 


\begin{tabular}{|c|c|c|c|c|c|}
\hline \multicolumn{6}{|c|}{ Third Round: Anxiety } \\
\hline & $\begin{array}{c}\text { Call } \\
\text { Volume }\end{array}$ & Gender & Race & $\begin{array}{l}\text { Education } \\
\text { Level }\end{array}$ & BMI \\
\hline & $\%$ Change & $\%$ Change & $\begin{array}{c}\% \\
\text { Change }\end{array}$ & $\begin{array}{c}\% \\
\text { Change }\end{array}$ & $\begin{array}{c}\% \\
\text { Change }\end{array}$ \\
\hline $\begin{array}{l}\text { Certification } \\
\text { Level }\end{array}$ & $0.00 \%$ & $0.88 \%$ & $0.00 \%$ & $0.00 \%$ & $0.00 \%$ \\
\hline $\begin{array}{l}\text { Service Type: } \\
\text { County }\end{array}$ & $0.60 \%$ & $2.41 \%$ & $0.00 \%$ & $0.60 \%$ & $0.00 \%$ \\
\hline $\begin{array}{l}\text { Service Type: } \\
\text { Private }\end{array}$ & $0.00 \%$ & $1.87 \%$ & $0.63 \%$ & $0.00 \%$ & $0.00 \%$ \\
\hline $\begin{array}{l}\text { Service Type: } \\
\text { Hospital }\end{array}$ & $1.38 \%$ & $2.76 \%$ & $0.00 \%$ & $3.45 \%$ & $0.69 \%$ \\
\hline $\begin{array}{l}\text { Service Type: } \\
\text { Other }\end{array}$ & $0.00 \%$ & $2.04 \%$ & $0.00 \%$ & $0.00 \%$ & $0.00 \%$ \\
\hline Age & $0.00 \%$ & $0.00 \%$ & $0.00 \%$ & $0.00 \%$ & $0.00 \%$ \\
\hline $\begin{array}{l}\text { Marital Status: } \\
\text { Divorced, } \\
\text { Widowed } \\
\text { Separated }\end{array}$ & $0.00 \%$ & $1.60 \%$ & $0.00 \%$ & $0.00 \%$ & $0.00 \%$ \\
\hline $\begin{array}{l}\text { Marital Status: } \\
\text { Never been } \\
\text { married }\end{array}$ & $0.00 \%$ & $0.81 \%$ & $0.00 \%$ & $0.81 \%$ & $0.81 \%$ \\
\hline $\begin{array}{l}\text { General Health: } \\
\text { Very Good }\end{array}$ & $0.55 \%$ & $0.55 \%$ & $0.00 \%$ & $0.55 \%$ & $0.55 \%$ \\
\hline $\begin{array}{l}\text { General Health: } \\
\text { Good }\end{array}$ & $0.26 \%$ & $0.52 \%$ & $0.00 \%$ & $0.78 \%$ & $2.08 \%$ \\
\hline $\begin{array}{l}\text { General Health: } \\
\text { Fair/Poor }\end{array}$ & $0.94 \%$ & $0.19 \%$ & $0.00 \%$ & $0.66 \%$ & $3.93 \%$ \\
\hline Exercise & $0.00 \%$ & $1.30 \%$ & $0.00 \%$ & $0.00 \%$ & $0.65 \%$ \\
\hline $\begin{array}{l}\text { Smoking: } \\
\text { Former/Ever }\end{array}$ & $0.00 \%$ & $0.74 \%$ & $0.00 \%$ & $0.74 \%$ & $0.74 \%$ \\
\hline $\begin{array}{l}\text { Smoking: } \\
\text { Current }\end{array}$ & $0.78 \%$ & $0.78 \%$ & $0.00 \%$ & $1.56 \%$ & $0.78 \%$ \\
\hline
\end{tabular}

**Race Removed as Possible Confounder 


\begin{tabular}{|l|c|c|c|c|}
\hline \multicolumn{5}{|c|}{ Fourth Round: Anxiety } \\
\hline & $\begin{array}{c}\text { Call } \\
\text { Volume }\end{array}$ & Gender & $\begin{array}{c}\text { Education } \\
\text { Level }\end{array}$ & BMI \\
\hline & Change & $\%$ Change & $\begin{array}{c}\% \\
\text { Change }\end{array}$ & $\begin{array}{c}\% \\
\text { Change }\end{array}$ \\
\hline $\begin{array}{l}\text { Certification } \\
\text { Level }\end{array}$ & $0.00 \%$ & $0.88 \%$ & $0.00 \%$ & $0.00 \%$ \\
\hline $\begin{array}{l}\text { Service Type: } \\
\text { County }\end{array}$ & $0.60 \%$ & $2.41 \%$ & $0.00 \%$ & $0.00 \%$ \\
\hline $\begin{array}{l}\text { Service Type: } \\
\text { Private }\end{array}$ & $0.63 \%$ & $2.52 \%$ & $0.63 \%$ & $0.63 \%$ \\
\hline $\begin{array}{l}\text { Service Type: } \\
\text { Hospital }\end{array}$ & $1.38 \%$ & $2.76 \%$ & $0.69 \%$ & $0.69 \%$ \\
\hline $\begin{array}{l}\text { Service Type: } \\
\text { Other }\end{array}$ & $0.00 \%$ & $2.04 \%$ & $0.00 \%$ & $0.00 \%$ \\
\hline Age & $0.00 \%$ & $0.00 \%$ & $0.00 \%$ & $0.00 \%$ \\
\hline $\begin{array}{l}\text { Marital Status: } \\
\text { Divorced, } \\
\text { Widowed } \\
\text { Separated }\end{array}$ & $0.00 \%$ & $1.60 \%$ & $0.00 \%$ & $0.00 \%$ \\
\hline $\begin{array}{l}\text { Marital Status: } \\
\text { Never been } \\
\text { married }\end{array}$ & $0.00 \%$ & $0.81 \%$ & $0.81 \%$ & $0.00 \%$ \\
\hline $\begin{array}{l}\text { General Health: } \\
\text { Very Good }\end{array}$ & $0.55 \%$ & $0.55 \%$ & $0.55 \%$ & $0.55 \%$ \\
\hline $\begin{array}{l}\text { General Health: } \\
\text { Good }\end{array}$ & $0.26 \%$ & $0.52 \%$ & $0.78 \%$ & $2.08 \%$ \\
\hline $\begin{array}{l}\text { General Health: } \\
\text { Fair/Poor }\end{array}$ & $0.94 \%$ & $0.28 \%$ & $0.66 \%$ & $3.93 \%$ \\
\hline Exercise & $0.00 \%$ & $1.30 \%$ & $0.00 \%$ & $0.65 \%$ \\
\hline $\begin{array}{l}\text { Smoking: } \\
\text { Former/Ever }\end{array}$ & $0.74 \%$ & $0.74 \%$ & $0.74 \%$ & $0.74 \%$ \\
\hline $\begin{array}{l}\text { Smoking: } \\
\text { Current }\end{array}$ & $0.78 \%$ & $0.78 \%$ & $1.56 \%$ & $0.78 \%$ \\
\hline
\end{tabular}

**Call Volume Removed as Possible Confounder 


\begin{tabular}{|c|c|c|c|}
\hline \multicolumn{4}{|c|}{ Fifth Round: Anxiety } \\
\hline & Gender & $\begin{array}{c}\text { Education } \\
\text { Level }\end{array}$ & BMI \\
\hline $\begin{array}{l}\text { Certification } \\
\text { Level }\end{array}$ & $0.88 \%$ & $0.88 \%$ & $0.00 \%$ \\
\hline $\begin{array}{l}\text { Service Type: } \\
\text { County }\end{array}$ & $2.40 \%$ & $0.00 \%$ & $0.00 \%$ \\
\hline $\begin{array}{l}\text { Service Type: } \\
\text { Private }\end{array}$ & $2.50 \%$ & $0.00 \%$ & $0.63 \%$ \\
\hline $\begin{array}{l}\text { Service Type: } \\
\text { Hospital }\end{array}$ & $2.72 \%$ & $0.00 \%$ & $0.00 \%$ \\
\hline $\begin{array}{l}\text { Service Type: } \\
\text { Other }\end{array}$ & $2.04 \%$ & $0.00 \%$ & $0.00 \%$ \\
\hline Age & $0.00 \%$ & $0.00 \%$ & $0.00 \%$ \\
\hline $\begin{array}{l}\text { Marital Status: } \\
\text { Divorced, } \\
\text { Widowed } \\
\text { Separated }\end{array}$ & $2.40 \%$ & $0.00 \%$ & $0.00 \%$ \\
\hline $\begin{array}{l}\text { Marital Status: } \\
\text { Never been } \\
\text { married }\end{array}$ & $1.63 \%$ & $0.81 \%$ & $0.00 \%$ \\
\hline $\begin{array}{l}\text { General Health: } \\
\text { Very Good }\end{array}$ & $0.55 \%$ & $0.00 \%$ & $1.10 \%$ \\
\hline $\begin{array}{l}\text { General Health: } \\
\text { Good }\end{array}$ & $0.00 \%$ & $0.78 \%$ & $2.08 \%$ \\
\hline $\begin{array}{l}\text { General Health: } \\
\text { Fair/Poor }\end{array}$ & $0.19 \%$ & $0.66 \%$ & $3.97 \%$ \\
\hline Exercise & $1.30 \%$ & $0.00 \%$ & $0.65 \%$ \\
\hline $\begin{array}{l}\text { Smoking: } \\
\text { Former/Ever }\end{array}$ & $0.00 \%$ & $0.74 \%$ & $0.00 \%$ \\
\hline $\begin{array}{l}\text { Smoking: } \\
\text { Current }\end{array}$ & $0.00 \%$ & $0.78 \%$ & $0.78 \%$ \\
\hline
\end{tabular}

**Education Level Removed as Possible Confounder 


\begin{tabular}{|c|c|c|}
\hline \multicolumn{3}{|c|}{ Sixth Round: Anxiety } \\
\hline & Gender & BMI \\
\hline $\begin{array}{l}\text { Certification } \\
\text { Level }\end{array}$ & $0.87 \%$ & $0.00 \%$ \\
\hline $\begin{array}{l}\text { Service Type: } \\
\text { County }\end{array}$ & $2.40 \%$ & $0.00 \%$ \\
\hline $\begin{array}{l}\text { Service Type: } \\
\text { Private }\end{array}$ & $2.50 \%$ & $0.63 \%$ \\
\hline $\begin{array}{l}\text { Service Type: } \\
\text { Hospital }\end{array}$ & $2.72 \%$ & $0.00 \%$ \\
\hline $\begin{array}{l}\text { Service Type: } \\
\text { Other }\end{array}$ & $2.04 \%$ & $0.00 \%$ \\
\hline Age & $0.00 \%$ & $0.00 \%$ \\
\hline $\begin{array}{l}\text { Marital Status: } \\
\text { Divorced, } \\
\text { Widowed } \\
\text { Separated }\end{array}$ & $1.60 \%$ & $0.00 \%$ \\
\hline $\begin{array}{l}\text { Marital Status: } \\
\text { Never been } \\
\text { married }\end{array}$ & $1.61 \%$ & $0.00 \%$ \\
\hline $\begin{array}{l}\text { General Health: } \\
\text { Very Good }\end{array}$ & $0.55 \%$ & $0.55 \%$ \\
\hline $\begin{array}{l}\text { General Health: } \\
\text { Good }\end{array}$ & $0.52 \%$ & $2.10 \%$ \\
\hline $\begin{array}{l}\text { General Health: } \\
\text { Fair/Poor }\end{array}$ & $0.19 \%$ & $3.71 \%$ \\
\hline Exercise & $0.65 \%$ & $0.65 \%$ \\
\hline $\begin{array}{l}\text { Smoking: } \\
\text { Former/Ever }\end{array}$ & $0.00 \%$ & $0.00 \%$ \\
\hline $\begin{array}{l}\text { Smoking: } \\
\text { Current }\end{array}$ & $0.00 \%$ & $5.51 \%$ \\
\hline
\end{tabular}

**BMI Removed as Possible Confounder 


\begin{tabular}{|c|c|}
\hline \multicolumn{2}{|c|}{ Seventh Round: Anxiety } \\
\hline & Gender \\
\hline $\begin{array}{l}\text { Certification } \\
\text { Level }\end{array}$ & $0.00 \%$ \\
\hline $\begin{array}{l}\text { Service Type: } \\
\text { County }\end{array}$ & $2.40 \%$ \\
\hline $\begin{array}{l}\text { Service Type: } \\
\text { Private }\end{array}$ & $1.86 \%$ \\
\hline $\begin{array}{l}\text { Service Type: } \\
\text { Hospital }\end{array}$ & $2.72 \%$ \\
\hline $\begin{array}{l}\text { Service Type: } \\
\text { Other }\end{array}$ & $2.04 \%$ \\
\hline Age & $0.00 \%$ \\
\hline $\begin{array}{l}\text { Marital Status: } \\
\text { Divorced, } \\
\text { Widowed } \\
\text { Separated }\end{array}$ & $1.60 \%$ \\
\hline $\begin{array}{l}\text { Marital Status: } \\
\text { Never been } \\
\text { married }\end{array}$ & $0.81 \%$ \\
\hline $\begin{array}{l}\text { General Health: } \\
\text { Very Good }\end{array}$ & $0.55 \%$ \\
\hline $\begin{array}{l}\text { General Health: } \\
\text { Good }\end{array}$ & $1.54 \%$ \\
\hline $\begin{array}{l}\text { General Health: } \\
\text { Fair/Poor }\end{array}$ & $0.83 \%$ \\
\hline Exercise & $0.65 \%$ \\
\hline $\begin{array}{l}\text { Smoking: } \\
\text { Former/Ever }\end{array}$ & $0.00 \%$ \\
\hline $\begin{array}{l}\text { Smoking: } \\
\text { Current }\end{array}$ & $0.79 \%$ \\
\hline
\end{tabular}




\section{Stress}

\begin{tabular}{|l|c|c|c|c|c|}
\hline \multicolumn{5}{|c|}{ First Round: Stress } \\
\hline & $\begin{array}{c}\text { Community } \\
\text { Size }\end{array}$ & Call Volume & Gender & $\begin{array}{c}\text { Marital } \\
\text { Status }\end{array}$ & BMI \\
\hline Certification Level & $0.77 \%$ & $0.76 \%$ & $0.00 \%$ & $0.00 \%$ & $0.00 \%$ \\
\hline Service Type: County & $0.8 \%$ & $0.80 \%$ & $1.60 \%$ & $0.00 \%$ & $0.80 \%$ \\
\hline Service Type: Private & $0.00 \%$ & $0.76 \%$ & $1.52 \%$ & $0.76 \%$ & $0.76 \%$ \\
\hline $\begin{array}{l}\text { Service Type: } \\
\text { Hospital }\end{array}$ & $0.00 \%$ & $0.85 \%$ & $0.85 \%$ & $0.00 \%$ & $0.00 \%$ \\
\hline Service Type: Other & $0.00 \%$ & $2.80 \%$ & $0.93 \%$ & $0.00 \%$ & $0.00 \%$ \\
\hline $\begin{array}{l}\text { Experience: 3-7 } \\
\text { Years }\end{array}$ & $0.00 \%$ & $0.00 \%$ & $0.00 \%$ & $0.00 \%$ & $0.00 \%$ \\
\hline $\begin{array}{l}\text { Experience: 8-15 } \\
\text { Years }\end{array}$ & $0.00 \%$ & $0.00 \%$ & $0.00 \%$ & $0.65 \%$ & $0.65 \%$ \\
\hline $\begin{array}{l}\text { Experience: } 16+ \\
\text { Years }\end{array}$ & $0.60 \%$ & $0.60 \%$ & $1.19 \%$ & $0.00 \%$ & $0.60 \%$ \\
\hline Age & $0.00 \%$ & $0.00 \%$ & $0.00 \%$ & $0.00 \%$ & $0.00 \%$ \\
\hline Race & $0.00 \%$ & $1.33 \%$ & $0.00 \%$ & $0.00 \%$ & $0.00 \%$ \\
\hline Education Level & $0.00 \%$ & $0.81 \%$ & $0.00 \%$ & $0.00 \%$ & $0.81 \%$ \\
\hline $\begin{array}{l}\text { General Health: Very } \\
\text { Good }\end{array}$ & $0.00 \%$ & $0.37 \%$ & $0.37 \%$ & $0.00 \%$ & $2.61 \%$ \\
\hline General Health: Good & $0.00 \%$ & $1.02 \%$ & $0.17 \%$ & $0.17 \%$ & $4.42 \%$ \\
\hline $\begin{array}{l}\text { General Health: } \\
\text { Fair/Poor }\end{array}$ & $0.00 \%$ & $0.00 \%$ & $0.00 \%$ & $0.00 \%$ & $0.57 \%$ \\
\hline Exercise & $0.00 \%$ & $0.57 \%$ & $0.57 \%$ & $0.57 \%$ & $0.57 \%$ \\
\hline $\begin{array}{l}\text { Smoking: } \\
\text { Former/Ever }\end{array}$ & $0.00 \%$ & $0.00 \%$ & $0.00 \%$ & $0.00 \%$ & $0.00 \%$ \\
\hline Smoking: Current & $0.00 \%$ & $0.00 \%$ & $0.00 \%$ & $0.00 \%$ & $0.74 \%$ \\
\hline
\end{tabular}

**Marital Status Removed as Possible Confounder 


\begin{tabular}{|l|c|c|c|c|}
\hline \multicolumn{5}{|c|}{ Second Round: Stress } \\
\hline & Community Size & Call Volume & Gender & BMI \\
\hline Certification Level & $0.77 \%$ & $0.76 \%$ & $0.76 \%$ & $0.00 \%$ \\
\hline Service Type: County & $0.80 \%$ & $0.80 \%$ & $1.60 \%$ & $0.80 \%$ \\
\hline Service Type: Private & $0.75 \%$ & $0.00 \%$ & $1.50 \%$ & $0.00 \%$ \\
\hline Service Type: Hospital & $0.00 \%$ & $0.85 \%$ & $1.71 \%$ & $0.85 \%$ \\
\hline Service Type: Other & $0.00 \%$ & $2.80 \%$ & $1.87 \%$ & $0.00 \%$ \\
\hline Experience: 3-7 Years & $0.00 \%$ & $0.00 \%$ & $0.00 \%$ & $0.00 \%$ \\
\hline $\begin{array}{l}\text { Experience: 8-15 } \\
\text { Years }\end{array}$ & $0.00 \%$ & $0.00 \%$ & $0.64 \%$ & $0.64 \%$ \\
\hline Experience: $16+$ Years & $0.60 \%$ & $0.60 \%$ & $1.19 \%$ & $0.60 \%$ \\
\hline Age & $0.00 \%$ & $0.00 \%$ & $0.00 \%$ & $0.00 \%$ \\
\hline Race & $0.00 \%$ & $1.33 \%$ & $1.33 \%$ & $0.00 \%$ \\
\hline Education Level & $0.81 \%$ & $0.81 \%$ & $0.81 \%$ & $0.81 \%$ \\
\hline $\begin{array}{l}\text { General Health: Very } \\
\text { Good }\end{array}$ & $0.00 \%$ & $0.00 \%$ & $0.00 \%$ & $0.63 \%$ \\
\hline General Health: Good & $0.37 \%$ & $0.37 \%$ & $0.00 \%$ & $2.61 \%$ \\
\hline $\begin{array}{l}\text { General Health: } \\
\text { Fair/Poor }\end{array}$ & $0.00 \%$ & $1.02 \%$ & $0.85 \%$ & $4.41 \%$ \\
\hline Exercise & $0.00 \%$ & $0.00 \%$ & $0.00 \%$ & $0.57 \%$ \\
\hline Smoking: Former/Ever & $0.00 \%$ & $0.00 \%$ & $0.00 \%$ & $0.00 \%$ \\
\hline
\end{tabular}

**Community Size Removed as Possible Confounder 


\begin{tabular}{|l|c|c|c|}
\hline \multicolumn{3}{|c|}{ Third Round: Stress } \\
\hline & Call Volume & Gender & BMI \\
\hline Certification Level & $1.54 \%$ & $0.00 \%$ & $0.00 \%$ \\
\hline Service Type: County & $0.00 \%$ & $0.79 \%$ & $0.00 \%$ \\
\hline Service Type: Private & $0.76 \%$ & $1.52 \%$ & $0.76 \%$ \\
\hline Service Type: Hospital & $0.00 \%$ & $1.71 \%$ & $0.00 \%$ \\
\hline Service Type: Other & $1.87 \%$ & $0.93 \%$ & $0.00 \%$ \\
\hline Experience: 3-7 Years & $0.00 \%$ & $0.00 \%$ & $0.00 \%$ \\
\hline $\begin{array}{l}\text { Experience: 8-15 } \\
\text { Years }\end{array}$ & $0.00 \%$ & $0.64 \%$ & $0.00 \%$ \\
\hline Experience: 16+ Years & $0.00 \%$ & $0.6 \%$ & $1.20 \%$ \\
\hline Age & $0.00 \%$ & $0.00 \%$ & $0.00 \%$ \\
\hline Race & $0.00 \%$ & $0.00 \%$ & $0.00 \%$ \\
\hline Education Level & $0.00 \%$ & $0.81 \%$ & $0.00 \%$ \\
\hline $\begin{array}{l}\text { General Health: Very } \\
\text { Good }\end{array}$ & $0.00 \%$ & $0.00 \%$ & $1.26 \%$ \\
\hline General Health: Good & $0.37 \%$ & $0.00 \%$ & $2.23 \%$ \\
\hline $\begin{array}{l}\text { General Health: } \\
\text { Fair/Poor }\end{array}$ & $1.02 \%$ & $0.17 \%$ & $4.58 \%$ \\
\hline Exercise & $0.00 \%$ & $0.57 \%$ & $0.57 \%$ \\
\hline Smoking: Former/Ever & $0.00 \%$ & $0.00 \%$ & $0.00 \%$ \\
\hline
\end{tabular}

**Call Volume Removed as Possible Confounder 


\begin{tabular}{|l|c|c|}
\hline \multicolumn{3}{|c|}{ Fourth Round: Stress } \\
\hline & Gender & BMI \\
\hline Certification Level & $0.00 \%$ & $0.00 \%$ \\
\hline Service Type: County & $0.79 \%$ & $0.00 \%$ \\
\hline Service Type: Private & $1.50 \%$ & $0.75 \%$ \\
\hline Service Type: Hospital & $0.85 \%$ & $0.00 \%$ \\
\hline Service Type: Other & $0.00 \%$ & $0.95 \%$ \\
\hline Experience: 3-7 Years & $0.00 \%$ & $0.00 \%$ \\
\hline $\begin{array}{l}\text { Experience: } 8-15 \\
\text { Years }\end{array}$ & $0.00 \%$ & $0.64 \%$ \\
\hline Experience: 16+ Years & $0.60 \%$ & $0.60 \%$ \\
\hline Age & $0.00 \%$ & $0.00 \%$ \\
\hline Race & $0.00 \%$ & $1.33 \%$ \\
\hline Education Level & $0.00 \%$ & $0.81 \%$ \\
\hline $\begin{array}{l}\text { General Health: Very } \\
\text { Good }\end{array}$ & $0.00 \%$ & $0.63 \%$ \\
\hline General Health: Good & $0.00 \%$ & $2.24 \%$ \\
\hline $\begin{array}{l}\text { General Health: } \\
\text { Fair/Poor }\end{array}$ & $0.17 \%$ & $4.63 \%$ \\
\hline Exercise & $0.57 \%$ & $0.57 \%$ \\
\hline Smoking: Former/Ever & $0.00 \%$ & $0.00 \%$ \\
\hline
\end{tabular}

**Gender Removed as Possible Confounder 


\begin{tabular}{|l|c|}
\hline \multicolumn{2}{|l|}{ Fifth Round: Stress } \\
\hline & BMI \\
\hline Certification Level & $0.00 \%$ \\
\hline Service Type: County & $0.79 \%$ \\
\hline Service Type: Private & $0.00 \%$ \\
\hline Service Type: Hospital & $0.00 \%$ \\
\hline Service Type: Other & $0.00 \%$ \\
\hline Experience: $3-7$ Years & $0.00 \%$ \\
\hline $\begin{array}{l}\text { Experience: } 8-15 \\
\text { Years }\end{array}$ & $0.65 \%$ \\
\hline Experience: $16+$ Years & $0.60 \%$ \\
\hline Age & $0.00 \%$ \\
\hline Race & $1.33 \%$ \\
\hline Education Level & $0.81 \%$ \\
\hline $\begin{array}{l}\text { General Health: Very } \\
\text { Good }\end{array}$ & $0.63 \%$ \\
\hline General Health: Good & $2.24 \%$ \\
\hline $\begin{array}{l}\text { General Health: } \\
\text { Fair/Poor }\end{array}$ & $4.28 \%$ \\
\hline Exercise & $0.00 \%$ \\
\hline Smoking: Former/Ever & $0.00 \%$ \\
\hline **BMI Removed as Possible Confounder \\
\hline
\end{tabular}


APPENDIX D

Stratification Tables to Assess Possible Interactions 
BMI and General Health

\begin{tabular}{|l|c|c|}
\hline \multicolumn{3}{|c|}{ BMI and General Health Interaction } \\
\hline \multicolumn{3}{|c|}{ Depression } \\
\hline & Normal BMI OR & Obese BMI OR \\
\hline Very Good* & 2.033 & 2.880 \\
\hline Good* & 3.999 & 5.751 \\
\hline Fair/Poor* & 15.971 & 18.164 \\
\hline
\end{tabular}

*Referent=Excellent

\section{BMI and General Health Interaction}

\begin{tabular}{|l|c|c|}
\hline \multicolumn{3}{|c|}{ Anxiety } \\
\hline & Normal BMI OR & Obese BMI OR \\
\hline Very Good* & 1.893 & 2.002 \\
\hline Good* & 4.834 & 4.480 \\
\hline Fair/Poor* & 16.040 & 13.612 \\
\hline
\end{tabular}

*Referent=Excellent

\begin{tabular}{|l|c|c|}
\hline \multicolumn{3}{|c|}{ BMI and General Health Interaction } \\
\hline \multicolumn{3}{|c|}{ Stress } \\
\hline & Normal BMI OR & Obese BMI OR \\
\hline Very Good* $^{*}$ & 1.708 & 1.657 \\
\hline Good* $^{*}$ & 3.238 & 2.962 \\
\hline Fair/Poor* & 8.489 & 7.587 \\
\hline
\end{tabular}

*Referent=Excellent 
General Health and Smoking

\begin{tabular}{|l|c|c|c|}
\hline \multicolumn{4}{|c|}{ Smoking and General Health Interaction } \\
\hline \multicolumn{3}{|c|}{ Depression } \\
\hline & Never Smoker OR & $\begin{array}{c}\text { Former/Ever } \\
\text { Smoker OR }\end{array}$ & $\begin{array}{c}\text { Current } \\
\text { Smoker } \text { OR }\end{array}$ \\
\hline Very Good* & 2.004 & 2.492 & 2.542 \\
\hline Good* & 4.252 & 4.165 & 5.227 \\
\hline Fair/Poor* & 11.613 & 24.937 & 15.556 \\
\hline
\end{tabular}

*Referent=Excellent

\begin{tabular}{|l|c|c|c|}
\hline \multicolumn{4}{|c|}{ Smoking and General Health Interaction } \\
\hline \multicolumn{4}{|c|}{ Anxiety } \\
\hline & $\begin{array}{c}\text { Never Smoker } \\
\text { OR }\end{array}$ & $\begin{array}{c}\text { Former/Ever } \\
\text { Smoker OR }\end{array}$ & $\begin{array}{c}\text { Current } \\
\text { Smoker } \text { OR }\end{array}$ \\
\hline Very Good* & 1.915 & 1.857 & 1.898 \\
\hline Good* & 4.272 & 4.303 & 4.437 \\
\hline Fair/Poor* & 11.818 & 21.419 & 11.718 \\
\hline
\end{tabular}

${ }^{*}$ Referent=Excellent

Smoking and General Health Interaction

\begin{tabular}{|l|c|c|c|}
\hline \multicolumn{4}{|c|}{ Stress } \\
\hline & $\begin{array}{c}\text { Never Smoker } \\
\text { OR }\end{array}$ & $\begin{array}{c}\text { Former/Ever } \\
\text { Smoker OR }\end{array}$ & $\begin{array}{c}\text { Current Smoker } \\
\text { OR }\end{array}$ \\
\hline Very Good* & 1.915 & 1.857 & 1.898 \\
\hline Good* $^{*}$ & 4.272 & 4.303 & 4.437 \\
\hline Fair/Poor* & 11.818 & 21.419 & 11.718 \\
\hline
\end{tabular}

*Referent=Excellent 
General Health and Exercise

\begin{tabular}{|c|c|c|}
\hline \multicolumn{3}{|c|}{ Exercise Status and General Health Interaction } \\
\hline \multicolumn{3}{|c|}{ Depression } \\
\hline & Yes Exercise OR & No Exercise OR \\
\hline Very Good* & 2.083 & 2.267 \\
\hline Good* & 3.941 & 3.450 \\
\hline Fair/Poor* & 12.297 & 11.589 \\
\hline
\end{tabular}

$*$ Referent=Excellent

\begin{tabular}{|l|c|c|}
\hline \multicolumn{3}{|c|}{ Exercise Status and General Health Interaction } \\
\hline \multicolumn{3}{|c|}{ Anxiety } \\
\hline & Yes Exercise OR & No Exercise OR \\
\hline Very Good* & 2.083 & 2.267 \\
\hline Good* & 3.941 & 3.950 \\
\hline Fair/Poor* & 12.297 & 11.589 \\
\hline
\end{tabular}

*Referent=Excellent

\begin{tabular}{|l|c|c|}
\hline \multicolumn{3}{|c|}{ Exercise Status and General Health Interaction } \\
\hline & Stress \\
\hline & 1.643 & No Exercise OR \\
\hline Very Good* & 3.118 & 1.837 \\
\hline Good* & 7.130 & 2.421 \\
\hline Fair/Poor* & & 6.170 \\
\hline
\end{tabular}

*Referent=Excellent 


\begin{tabular}{|l|c|c|}
\hline \multicolumn{3}{|c|}{ Race and Education } \\
\hline \multicolumn{3}{|c|}{ Depression } \\
\hline & Less than College Degree OR & College Degree OR \\
\hline Non-Minority & Referent & Referent \\
\hline Minority & 1.416 & 1.569 \\
\hline
\end{tabular}

\begin{tabular}{|l|c|c|}
\hline \multicolumn{3}{|c|}{ Race and Education } \\
\hline \multicolumn{3}{|c|}{ Anxiety } \\
\hline & Less than College Degree OR & College Degree OR \\
\hline Non-Minority & Referent & Referent \\
\hline Minority & 1.141 & 1.218 \\
\hline
\end{tabular}

\begin{tabular}{|l|c|c|}
\hline \multicolumn{3}{|c|}{ Race and Education } \\
\hline \multicolumn{3}{|c|}{ Stress } \\
\hline & Less than College Degree OR & College Degree OR \\
\hline Non-Minority & Referent & Referent \\
\hline Minority & 1.638 & 1.550 \\
\hline
\end{tabular}


Race and Community Size

\begin{tabular}{|l|c|c|}
\hline \multicolumn{3}{|c|}{ Race and Community Size } \\
\hline \multicolumn{3}{|c|}{ Depression } \\
\hline & Non-Minority OR & Minority OR \\
\hline Small Community & Referent & Referent \\
\hline Large Community & 0.901 & 0.832 \\
\hline
\end{tabular}

\begin{tabular}{|l|c|c|}
\hline \multicolumn{3}{|c|}{ Race and Community Size } \\
\hline \multicolumn{3}{|c|}{ Anxiety } \\
\hline & Non-Minority OR & Minority OR \\
\hline Small Community & Referent & Referent \\
\hline Large Community & 1.014 & 0.867 \\
\hline
\end{tabular}

\begin{tabular}{|l|c|c|}
\hline \multicolumn{3}{|c|}{ Race and Community Size } \\
\hline \multicolumn{3}{|c|}{ Stress } \\
\hline & Non-Minority OR & Minority OR \\
\hline Small Community & Referent & Referent \\
\hline Large Community & 0.843 & 0.864 \\
\hline
\end{tabular}


Certification Level and Years of Experience

\begin{tabular}{|l|c|c|}
\hline \multicolumn{3}{|c|}{ Certification Level and Years of Experience } \\
\hline \multicolumn{3}{|c|}{ Depression } \\
\hline & EMT-Basic OR & Paramedic OR \\
\hline 3-7 years* & 0.761 & 0.960 \\
\hline 8-15 years* & 1.059 & 1.251 \\
\hline$\geq 16$ years* & 1.259 & 1.409 \\
\hline
\end{tabular}

$*$ Referent $=\leq 2$ Years

\begin{tabular}{|l|c|c|}
\hline \multicolumn{3}{|c|}{ Certification Level and Years of Experience } \\
\hline \multicolumn{3}{|c|}{ Anxiety } \\
\hline & $\begin{array}{c}\text { EMT-Basic } \\
\text { OR }\end{array}$ & Paramedic OR \\
\hline 3-7 years* & 0.882 & 0.871 \\
\hline 8-15 years* & 0.839 & 0.957 \\
\hline$\geq 16$ years* & 0.820 & 0.835 \\
\hline
\end{tabular}

$*$ Referent $=\leq 2$ Years

\begin{tabular}{|l|c|c|}
\hline \multicolumn{3}{|c|}{ Certification Level and Years of Experience } \\
\hline \multicolumn{3}{|c|}{ Stress } \\
\hline & $\begin{array}{c}\text { EMT-Basic } \\
\text { OR }\end{array}$ & Paramedic OR \\
\hline 3-7 years* & 1.024 & 1.170 \\
\hline 8-15 years* & 1.202 & 1.565 \\
\hline$\geq 16$ years* & 1.132 & 1.326 \\
\hline
\end{tabular}

$*$ Referent $=\leq 2$ Years 